\title{
Undirected health IT implementation in ambulatory care favors paper-based workarounds and limits health data exchange
}

\author{
Djalali, Sima ; Ursprung, Nadine ; Rosemann, Thomas ; Senn, Oliver ; Tandjung, Ryan
}

\begin{abstract}
BACKGROUND: The adoption and use of health information technology (IT) continues to grow around the globe. In Switzerland, the government nor professional associations have to this day provided incentives for health IT adoption. OBJECTIVE: We aim to assess the proportion of physicians who are routinely working with electronic health data and describe to what extent physicians exchange electronic health data with peers and other health care providers. Additionally, we aim to estimate the effect of physicians' attitude towards health IT on the adoption of electronic workflows. METHODS: Between May and July 2013, we conducted a crosssectional survey of 1200 practice based physicians in Switzerland. Respondents were asked to report on their technical means and where applicable their paper-based workarounds to process laboratory data, examination results, referral letters and physician's letters. Physicians' view of barriers and facilitators towards health IT use was determined by a composite score. RESULTS: A response rate of $57.1 \%(n=685)$ was reached. The sample was considered to be representative for physicians in Swiss ambulatory care. $35.2 \%$ of the respondents documented patients' health status with the help of a longitudinal semi-structured electronic text record generated by one or more encounters in the practice. Depending on the task within a workflow, around 11-46\% of the respondents stated to rely on electronic workflow practices to process laboratory and examination data and dispatch referral notes and physician's letters. The permanent use of electronic workflow processes was infrequent. Instead, respondents reported paper-based workarounds affecting specific tasks within a workflow. Physicians' attitude towards health IT was significantly associated with the adoption of electronic workflows (OR 1.04-1.31, p<0.05), but the effect sizes of factors related to the working environment (e.g., regional factors, medical specialty, type of practice) were larger. CONCLUSION: At present, only a few physicians in Swiss ambulatory care routinely work with electronic health data. Until more of their peers participate in electronic exchange of structured clinical information, most physicians will continue to stay in paper-based systems and workarounds. The survey found that physicians with a positive attitude towards health IT were more likely to adopt electronic workflows, but the impact is minor. It will likely be necessary to introduce financial incentives and develop national standards in order to promote the adoption by a critical mass of practicing clinicians.
\end{abstract}

DOI: https://doi.org/10.1016/j.ijmedinf.2015.08.001

Posted at the Zurich Open Repository and Archive, University of Zurich ZORA URL: https://doi.org/10.5167/uzh-112686

Journal Article

Accepted Version

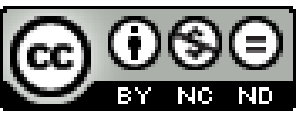

The following work is licensed under a Creative Commons: Attribution-NonCommercial-NoDerivatives 4.0 International (CC BY-NC-ND 4.0) License. 
Originally published at:

Djalali, Sima; Ursprung, Nadine; Rosemann, Thomas; Senn, Oliver; Tandjung, Ryan (2015). Undirected health IT implementation in ambulatory care favors paper-based workarounds and limits health data exchange. International journal of medical informatics, 84(11):920-932.

DOI: https://doi.org/10.1016/j.ijmedinf.2015.08.001 
Last Manuscript before press

Djalali S, Ursprung N, Rosemann T, Senn O, Tandjung R: Undirected health IT implementation in ambulatory care favors paper-based workarounds and limits health data exchange. International Journal of Medical Informatics 2015; DOI: 10.1016/j.ijmedinf.2015.08.001. [Epub ahead of print]

Undirected health IT implementation in ambulatory care favors paper-based workarounds and limits health data exchange

Sima Djalalia ${ }^{\mathrm{a}, *}$, Nadine Ursprung ${ }^{\mathrm{a}}$, Thomas Rosemann ${ }^{\mathrm{a}}$, Oliver Senn ${ }^{\mathrm{a}}$, Ryan Tandjung $^{\mathrm{a}}$

${ }^{a}$ Institute of Primary Care and Health Services Research, University of Zurich, University Hospital Zurich, Switzerland

${ }^{*}$ Corresponding author at:

Institute of Primary Care

University of Zurich, University Hospital Zurich

Pestalozzistrasse 24

$\mathrm{CH}-8091$ Zurich

Tel: +41442557504

sima.djalali@usz.ch

Key words: health information technology, electronic health record, Switzerland, ambulatory care, implementation, barriers 
Last Manuscript before press

Djalali S, Ursprung N, Rosemann T, Senn O, Tandjung R: Undirected health IT implementation in ambulatory care favors paper-based workarounds and limits health data exchange. International Journal of Medical Informatics 2015; DOI: 10.1016/j.ijmedinf.2015.08.001. [Epub ahead of print]

\section{Abstract}

\section{Background}

The adoption and use of health information technology (IT) continues to grow around the globe. In Switzerland, the government nor professional associations have to this day provided incentives for health IT adoption.

\section{Objective}

We aim to assess the proportion of physicians who are routinely working with electronic health data and describe to what extent physicians exchange electronic health data with peers and other health care providers. Additionally, we aim to estimate the effect of physicians' attitude towards health IT on the adoption of electronic workflows.

\section{Methods}

Between May and July 2013, we conducted a cross-sectional survey of 1200 practice based physicians in Switzerland. Respondents were asked to report on their technical means and where applicable their paper-based workarounds to process laboratory data, examination results, referral letters and physician's letters. Physicians' view of barriers and facilitators towards health IT use was determined by a composite score.

\section{Results}

A response rate of $57.1 \%(n=685)$ was reached. The sample was considered to be representative for physicians in Swiss ambulatory care. $35.2 \%$ of the respondents documented patients' health status with the help of a longitudinal semi-structured electronic text record generated by one or more encounters in the practice. Depending on the task within a workflow, around $11-46 \%$ of the respondents stated to rely on electronic workflow practices to process laboratory and examination data and dispatch referral notes and physician's letters. The permanent use of electronic workflow processes was infrequent. Instead, respondents reported paper-based workarounds affecting specific tasks within a workflow. Physicians' attitude towards health IT was significantly associated with the adoption of electronic workflows (OR 1.04-1.31, p<0.05), but the effect sizes of factors related to the working environment (e.g. regional factors, medical specialty, type of practice) were larger. 
Last Manuscript before press

Djalali S, Ursprung N, Rosemann T, Senn O, Tandjung R: Undirected health IT implementation in ambulatory care favors paper-based workarounds and limits health data exchange. International Journal of Medical Informatics 2015; DOI: 10.1016/j.ijmedinf.2015.08.001. [Epub ahead of print]

\section{Conclusion}

At present, only a few physicians in Swiss ambulatory care routinely work with electronic health data.

Until more of their peers participate in electronic exchange of structured clinical information, most physicians will continue to stay in paper-based systems and workarounds. The survey found that physicians with a positive attitude towards health IT were more likely to adopt electronic workflows, but the impact is minor. It will likely be necessary to introduce financial incentives and develop national standards in order to promote the adoption by a critical mass of practicing clinicians. 


\section{Last Manuscript before press}

Djalali S, Ursprung N, Rosemann T, Senn O, Tandjung R: Undirected health IT implementation in ambulatory care favors paper-based workarounds and limits health data exchange. International Journal of Medical Informatics 2015; DOI: 10.1016/j.ijmedinf.2015.08.001. [Epub ahead of print]

\section{Introduction}

The adoption and use of health information technology (IT) continues to grow in many healthcare settings around the globe [1-4]. However, countries still vary considerably in their development and are at different stages of maturity in realizing a seamless exchange of medical patient information between different healthcare providers [4-6]. The basic prerequisite for achieving extensive health information exchange in any country is a comprehensive implementation of Electronic Health Records (EHRs) at the micro level of healthcare (i.e. among healthcare providers), since EHRs form the core of any eHealth system [7]. Thus, previous implementation research often used the availability of an EHR application as a surrogate parameter of a successful implementation of eHealth in the sense of routine healthcare practice supported by electronic processes and communication. This led policy makers to base national eHealth strategies largely on measures to accelerate the adoption of EHR systems [811]. Especially studies on barriers to the acceptance of eHealth and frameworks for the assessment of eHealth readiness tend to focus particularly on healthcare providers' views of EHRs $[7,12-16]$. The problem is, however, that this approach neglects the great variety of EHR definitions and potentially available EHR functionalities. Therefore, recent research evaluating the implementation of eHealth distinguishes more sharply between the simple availability of "any type" of EHR system and types that meet the criteria of the "Meaningful Use" objectives and provide multifunctional health information capacity including the capability to perform health information exchange $[1,17-19]$. Indeed, results in many countries show a substantial gap between the proportion of healthcare providers using EHRs and those having multifunctional capacity $[1,5,20]$. This indicates that either only a fraction of EHR systems provides multifunctional capacity to date or that healthcare providers use only a fraction of available EHR functionalities. In addition, there is an increasing number of reports on health IT functionalities (e.g. Clinical Decision Support Systems, Computerized Provider Order Entry Systems) that are not EHR-embedded or the reports do not provide explicit information on their system architecture, respectively [19]. What is missing today, are more detailed descriptions of the architecture of health IT applications under study, content and format of data contained within their repositories, their cross-linkage to other health IT applications and other data sources. Moreover, information about the context and degree of use in daily clinical practice is missing. As a result, 1) there exist multiple, occasionally contradictory definitions and terminologies in the context of health IT applications $[4,21,22]$; 


\section{Last Manuscript before press}

Djalali S, Ursprung N, Rosemann T, Senn O, Tandjung R: Undirected health IT implementation in ambulatory care favors paper-based workarounds and limits health data exchange. International Journal of Medical Informatics 2015; DOI: 10.1016/j.ijmedinf.2015.08.001. [Epub ahead of print] 2 ) it is difficult to determine the maturity of any health IT application not to mention of an entire eHealth system especially in countries with an heterogeneous marketplace and a variety of software applications in use (e.g. The United States, Germany, Switzerland) [9,23-25];

3) contextual and implementation related barriers and facilitating factors to the effective use of existing systems are only superficially described $[19,26]$;

4) comparisons between different systems both on a national and international level are subject to limitations and cross-site learning about effective implementation is made difficult [27].

The present study aims to describe the status quo of health IT implementation in Swiss ambulatory care in a different way without relying on ambiguous terminology or describing specific software applications. Our objectives are:

1) to assess the proportion of physicians routinely working with electronic health data;

2) to clarify what proportion of these electronic health data is available in a structured electronic format theoretically facilitating seamless electronic data exchange;

3) to describe to what extent physicians already exchange structured and/or unstructured electronic health data with peers and other health care providers to date.

We will focus on physicians' means to continuously document patients health status, manage patients' consultations and organize three common workflows in ambulatory care requiring information exchange between physicians and other healthcare providers: processing of laboratory data, processing of examination results and administration of referral notes and physician's letters.

So, it will be possible to gain an overview of Swiss physicians' health IT use in daily practice. Readers may ask themselves the question how comparable workflows are usually organized in their own country, healthcare system or clinical unit and use our description of the situation in Switzerland as a benchmark for the maturity of health IT implementation in their own environment.

Additionally, we aim to assess physicians' views of the consequences of health IT use in daily practice and to evaluate the impact of these attitudes on physicians' choice to adopt electronic workflows. This will contribute to a better understanding of barriers and facilitating factors to physicians' acceptance of health IT. To date, the majority of studies on acceptance factors originate from the United States [16]. Switzerland, by contrast, is a particularly interesting country to study in this context, because it is a high income European country with physicians in ambulatory care working as self-employed entrepreneurs. So, one could assume that physicians have enough spending power to implement 
Last Manuscript before press

Djalali S, Ursprung N, Rosemann T, Senn O, Tandjung R: Undirected health IT implementation in ambulatory care favors paper-based workarounds and limits health data exchange. International Journal of Medical Informatics 2015; DOI: 10.1016/j.ijmedinf.2015.08.001. [Epub ahead of print] health IT if they see any advantages in doing so. The government has to this day not provided incentives for health IT adoption.

\section{Material and Methods}

Between May and July 2013, we conducted a cross-sectional survey of practice based physicians in Switzerland. All physicians registered as working in outpatient care based in practices or medical centers without hospital affiliation were eligible. Hospital based physicians were excluded because they have no influence on the use of health IT in their organization. According to the latest available census at the time of the study preparation, 16,232 physicians met these inclusion criteria [28]. For a sample of 376 , the margin of sample error would have been $5 \%$ at the $95 \%$ confidence interval. Presuming a response rate of $30-40 \%, 940$ addressees would have been required. We decided to extend the number of addressees up to 1200 in order to allow for subgroup analyses of physicians from different specialties and comparisons with a previous survey in Swiss ambulatory care that had addressed 1200 physicians [29]. Our study was designed as a mixed-modes survey with a selfadministered questionnaire. Addressees were randomly selected from the address database of the Swiss Medical Association and contacted by letter on behalf of the Institute of Primary Care, University of Zurich, University Hospital Zurich. Respondents could choose to return the completed questionnaire by mail (postpaid envelopes were provided), fax or an online survey platform (Surveymonkey®). Four weeks after the initial mailing, non-responders received another invitation. After six weeks, the survey was closed.

According to Swiss law a survey among physicians does not require a vote of the Ethical Committee. During the period of data collection, responses and address data of respondents were linked in order to monitor responsiveness of addressees. Prior to data analysis, this link was deleted ensuring complete anonymization. As an incentive offer to encourage participation in the survey, a draw for 10 tablet computers and book vouchers (worth CHF 150) was launched. Participation in the draw was optional and open to all addressees independent of their participation in the survey. Therefore, separate postpaid postcards were made available. 


\section{Last Manuscript before press}

Djalali S, Ursprung N, Rosemann T, Senn O, Tandjung R: Undirected health IT implementation in ambulatory care favors paper-based workarounds and limits health data exchange. International Journal of Medical Informatics 2015; DOI: 10.1016/j.ijmedinf.2015.08.001. [Epub ahead of print] 2.2 Outcome definitions

Primary outcome measures of the survey were:

- Use of a self-contained EHR application: proportion of physicians routinely documenting patients' anamnesis and current health status (including medication, immunization and allergies) using a self-contained EHR application in the sense of a longitudinal semi-structured electronic text record generated by one or more encounters in the practice. Respondents who reported to document a set of predefined health information as depicted in Table 1 electronically were considered to be EHR adopters;

- Standardized encoding of health data: proportion of physicians encoding patients' symptoms, diagnoses and medical conditions electronically according to a standardized medical classification;

- Use of electronic billing systems and times schedules: proportion of physicians routinely using such electronic features to manage patients' consultations;

- Processing of laboratory data: distribution of electronic and paper-based workflow practices of ordering laboratory tests, receiving and archiving the respective results;

- Processing of examination results: distribution of electronic and paper-based workflow practices of documenting and archiving examination results;

- Administration of referrals and physician's letters: distribution of electronic and paper-based workflow practices of dispatching and archiving referral notes and physician's letters.

Secondary outcomes were:

- the proportion of physicians always processing structured electronic laboratory data;

- the proportion of physicians converting paper-based laboratory reports to an electronic data format;

- the proportion of physicians always gathering structured electronic examination data;

- the proportion of physicians converting paper-based examination reports to an electronic data format;

- Intention to expand health IT use: the proportion of physicians' planning to expand their use of health IT within the next 3 years;

- Physicians' attitude towards health IT: a composite score of physicians' rating of health IT related impacts on operating costs, expenditures of time, cooperation with other physicians, 


\section{Last Manuscript before press}

Djalali S, Ursprung N, Rosemann T, Senn O, Tandjung R: Undirected health IT implementation in ambulatory care favors paper-based workarounds and limits health data exchange. International Journal of Medical Informatics 2015; DOI: 10.1016/j.ijmedinf.2015.08.001. [Epub ahead of print] quality of care, workflow management, physicians' ability to get an overview of patients' situation and physician-patient-relationship as surrogate of their attitude towards health IT;

- Impact of physicians' attitude: the effect of physicians' attitude towards health IT on health IT adoption, use of electronic workflow practices and the intention to expand individual health IT use in the future.

\subsection{Questionnaire}

The questionnaire was specifically developed for study purposes and pretested regarding comprehensibility and usability by 24 physicians representing the target group. A review of the random address sample found that none of the pilot testers was later a part of the study population. After pilot testing, the original German questionnaire was translated into French according to guidelines for obtaining semantic, idiomatic, experiential and conceptual equivalence in translation by using backtranslation techniques and committee review [30]. An Italian version was not developed, since citizens of the Italian-speaking part of Switzerland generally speak French or German as a second language.

The questionnaire was composed of 31 items, thereof 5 items referred to respondents' demographics. The other items referred to the IT infrastructure (2 items), the use of health IT functionalities for health status documentation ( 6 items) billing and time scheduling ( 2 items), the im- and export ( 7 items) and exchange (6 items) of laboratory values, examination results and referral information, physicians' views of health IT impacts (2 items) and the intention to extent the use of health IT in the near future (1 item). Twenty-eight items were designed as multiple-choice questions with a set of maximum 5 options representing ordinal or nominal response categories. Two items were designed as multiple response items. Physicians' perceptions of health IT related impacts on operating costs, expenditures of time, cooperation with other physicians, quality of care, workflow management, physicians' ability to get an overview of patients' situation and physician-patient-relationship were assessed using a 5-point-LikertScale rating of 6 items and 1 ordinal 4-point scale question. We designed the respective items according to literature indicating that the concepts underlying these items reflect important motivational forces (e.g. healthcare providers' (dis-)satisfaction with the status quo, perceived ease of use, perceived usefulness) and socio-technical factors that can facilitate or limit the adoption of health IT in healthcare professionals [5,14,16,29,31-39]. From the data obtained, a composite score was calculated as surrogate of an individual's attitude towards health IT. The lowest achievable score was 


\section{Last Manuscript before press}

Djalali S, Ursprung N, Rosemann T, Senn O, Tandjung R: Undirected health IT implementation in ambulatory care favors paper-based workarounds and limits health data exchange. International Journal of Medical Informatics 2015; DOI: 10.1016/j.ijmedinf.2015.08.001. [Epub ahead of print] 7 points and was considered as surrogate of a mind attaching great importance to barriers towards

health IT adoption, whereas higher scores (maximum 34 points) would correspond to a more positive minded person less aware of barriers. The original questionnaire is provided in Appendix A.

\subsection{Data analysis}

We used descriptive statistics to assess the distribution of responses overall and in subgroups of different age, sex, language regions, medical specialization, type of practice (single handed vs. group practice), duration of practice career and EHR adoption. Data are presented as frequencies and percentages. Baseline characteristics of the respondents were compared using Chi-square test or Student's t-test where appropriate.

Logistic regression was performed in order to gauge the effect of age, sex, language region, medical specialization, type of practice and physicians' attitude towards health IT on all primary and secondary outcomes. Where applicable, models were controlled for EHR adoption status. The estimates are presented as odds ratios (OR) with $95 \%$ confidence intervals $(95 \% \mathrm{Cl})$ and $\mathrm{p}$-values. A p-value of $<0.05$ was considered as statistically significant. The duration of physicians' career in practice was excluded from statistical modeling, because this variable highly correlated with physicians' age (Pearson's coefficient rho $=0.81$ ).

All statistical analyses were done in $\mathrm{R}$ (version 3.0.2, The R Foundation for Statistical Computing, Vienna, Austria).

\section{Results}

According to the power calculation, 1200 Swiss physicians were addressed; thereof 685 returned the questionnaire corresponding to a response rate of $57.1 \%$. Addresses were unique, so every respondent represented a separate practice. Response rates in the German, French and Italian speaking regions did not differ significantly $(p=0.7)$.

Eighteen $(2.6 \%)$ responses were excluded from analysis because respondents stated to work in a hospital-associated, not practice-based, setting (17 cases) or forbade the analysis of their results (1 case), respectively. Thus, the responses of 667 respondents (55.6\% of all addressees) were included. Their characteristics are depicted in Table 2. Compared to male respondents, women were slightly 


\section{Last Manuscript before press}

Djalali S, Ursprung N, Rosemann T, Senn O, Tandjung R: Undirected health IT implementation in ambulatory care favors paper-based workarounds and limits health data exchange. International Journal of Medical Informatics 2015; DOI: 10.1016/j.ijmedinf.2015.08.001. [Epub ahead of print] younger (mean difference 5 years; $p<0.001)$, more likely to work in group practices $(p<0.001)$ and prevailed in the subgroup of gynaecologists $(55.8 \%)$.

\subsection{Use of a self-contained EHR application}

The majority of respondents $(95.5 \%, n=637 / 667)$ stated that their practice was equipped with at least one computer. Thereof, $98.0 \%(n=624 / 637)$ had internet access. In most cases $(75.0 \%, n=478 / 637)$, physicians had a computer at their disposal in the consulting room, whereas $25.0 \%$ ( $n=159 / 637)$ used computers solely at the reception desk and/or in the back-office. Based on the identification scheme presented in section $2.2,35.2 \%(n=235 / 667)$ of all respondents were considered to use a selfcontained EHR application. Eight respondents (1.2\%) were excluded from further analysis regarding EHR use because they missed to report on the items underlying the identification scheme. Thirty respondents $(4.5 \%)$ had not any computer at their disposal and were therefore excluded. The remaining respondents with computer access $(n=394)$ were classified as non-EHR-adopters using paper and pen for record keeping. For the most part $(98.2 \%, n=387 / 394), \geq 2$ criteria of EHR adopters were not met. Most often $(92.9 \%, n=366 / 394)$, the criterion of documenting the anamnesis and current health status of patients electronically was not met. Moreover, $85.8 \%$ ( $n=338 / 394)$ used neither electronic drug plans nor IT functionalities for the documentation of immunizations or allergies.

The distribution of EHR adopters and non-adopters differed significantly between subgroups of different age, language region, medical specialization, practice type and duration of practice career (Table 3). EHR adoption was highest among respondents 30-49 years of age, male, German speaking, working as GP, being affiliated to a group practice, with 0-10 years of career in practice (Table 4). Physicians aged $\geq 50$ years and those working in single-handed practices were more likely not to have any computer or to have computers for reception/office purposes only. Among psychiatrists, the absence of computers was highest (18.7\%) compared to members of other medical specialties.

\subsection{Standardized encoding of health data}

While $80.0 \%(n=188 / 235)$ of EHR adopters stated to record patients' current medical problems with the help of an electronic short list, the use of medical classifications supporting a structuring and standardization of these lists was infrequently reported. In total, $27.1 \%(n=51 / 188)$ of short list users 


\section{Last Manuscript before press}

Djalali S, Ursprung N, Rosemann T, Senn O, Tandjung R: Undirected health IT implementation in ambulatory care favors paper-based workarounds and limits health data exchange. International Journal of Medical Informatics 2015; DOI: 10.1016/j.ijmedinf.2015.08.001. [Epub ahead of print] encoded symptoms, diagnoses and medical conditions according to a generally accepted medical classification instead of their own words. Thereof, $41.2 \% \quad(n=21 / 50)$ used the International Classification of Primary Care (ICPC-2) [40] whereas the rest $(58.8 \%, n=30 / 51)$ used the International Classification of Diseases (ICD-10) [41] or other unspecified classifications. Comparing subgroups of different age, sex, language region, medical specialization, type of practice and duration pf practice career, equal distributions were found.

\subsection{Use of electronic billing systems and time schedules}

Overall, $75.1 \%(n=501 / 667)$ of the respondents stated to use electronic billing systems and $49.3 \%$ $(n=329 / 667)$ used electronic time schedules to manage their patients' consultations. In both cases, EHR adoption was the most important predictor (OR 4.82, 95\% $\mathrm{Cl} 2.45-9.49$ and $\mathrm{OR} 11.04,95 \% \mathrm{Cl}$ $6.41-19.03, p<0.001$ for both). Electronic billing systems were used by $94.0 \%$ ( $n=221 / 235)$ of EHR adopters and $69.5 \%(n=274 / 394)$ of non-EHR-adopters, respectively. In comparison, electronic time schedules were used by $88.1 \%(n=207 / 235)$ and $29.4 \%(n=116 / 394)$, respectively. Being affiliated to a group practice ( $\geq 2$ physicians) had additional impact on the use of electronic time schedules (Table 4).

\subsection{Processing of laboratory data}

We assessed the workflow practices with regard to the following processes:

- ordering laboratory tests

- receiving the respective laboratory results

- $\quad$ archiving the results.

In total, $63.9 \%(n=426 / 667)$ of the survey respondents worked in a practice providing in-house laboratory services and $87.9 \%(n=586 / 667)$ cooperated with an external laboratory service provider. Overall, paper-based workflow practices prevailed independent of type of laboratory service. Respondents reported to order laboratory tests predominantly by written/verbal instructions or preprinted order forms, to receive paper-based reports of the results (letter/fax) and to archive these reports in a paper-based patient record. Around $17.0 \%$ of the respondents stated to use electronic laboratory order systems. By contrast, the proportion of respondents who stated to always rely on electronic order systems and structured data exchange was $6.1 \%(n=26 / 426)$ in case of in-house laboratory services and $4.2 \%(n=25 / 586)$ in case of external laboratory services. 


\section{Last Manuscript before press}

Djalali S, Ursprung N, Rosemann T, Senn O, Tandjung R: Undirected health IT implementation in ambulatory care favors paper-based workarounds and limits health data exchange. International Journal of Medical Informatics 2015; DOI: 10.1016/j.ijmedinf.2015.08.001. [Epub ahead of print] In sum, $29.1 \%$ of the respondents with access to an in-house laboratory service and $49.3 \%$ of the respondents with external provider received the results in a structured electronic data format that allows for automatic integration of the results into a preexisting laboratory record (Table 5). However, most of these respondents also explained to use non-electronic pathways besides and to process electronic data as well as non-electronic laboratory data at the same time, whereby non-electronic data (letters/fax) prevailed. Thus, on average $54.6 \%$ of the results that physicians received from inhouse laboratories and $87.9 \%$ of the results they received from external laboratory services were in paper format. Overall, $19.6 \%$ of the respondents explained to convert paper-based laboratory reports from in-house laboratory services to an electronic format, whereas $18.4 \%$ stated to convert at paperbased reports of external laboratory services (Table 5).

Respondents working as a GP, those being affiliated to a group practice and using a self-contained EHR application were most likely to adopt electronic workflow practices. German speaking respondents were less likely to use electronic order systems than French or Italian speaking respondents but more likely to receive results in a structured electronic data format (Table 4).

\subsection{Processing of examination results}

We assessed the workflow practices with regard to the following processes:

- documentation and archiving of results from diagnostic examinations (x-ray, sonography, electrocardiogram [ECG], and spirometry) undertaken in the practice

- archiving of examination results received from external healthcare providers.

The majority of respondents $(>70 \%)$ who performed the abovementioned diagnostic examinations stated to print and archive the respective examination results in a paper-based patient record.

Concerning imaging diagnostics (x-ray, sonography), around $26.0 \%$ of the respondents stated to generate digital images that are automatically transferred to an electronic examination record. In contrast, respondents who performed load tests with continuous data capturing (ECG, spirometry), generated structured data in around $16.0 \%$ of cases (Table 5).

If Swiss physicians receive examination reports from external healthcare providers, these reports may be either paper documents (letter/fax) or electronic (Portable Document Format [PDF]) documents. Structured electronic reports do not exist in this case. Nine respondents $(1.3 \%, n=9 / 667)$ stated to 


\section{Last Manuscript before press}

Djalali S, Ursprung N, Rosemann T, Senn O, Tandjung R: Undirected health IT implementation in ambulatory care favors paper-based workarounds and limits health data exchange. International Journal of Medical Informatics 2015; DOI: 10.1016/j.ijmedinf.2015.08.001. [Epub ahead of print] receive PDF documents only, whereas $44.4 \%(n=296 / 667)$ of the respondents stated to receive paper

documents only. The majority $(53.7 \%, \mathrm{n}=358 / 667)$ stated to receive examination reports in paper as well as PDF format in daily practice, whereby paper documents prevailed. The proportion of respondents receiving more than $50 \%$ of examination reports in PDF format was $11.4 \%$ ( $n=42 / 367)$. Almost one third $(33.2 \%, n=217 / 654)$ of the respondents who received paper-based examination reports explained that they converted these to an electronic format. The others stored the paper-based reports in a paper-based patient record. In comparison, $54.2 \%(n=199 / 367)$ of the respondents who received examination reports in PDF format explained to store the documents in a digital storage. The others printed the PDF files and stored it in a paper-based patient record (Table 5). Male, German speaking respondents, those being affiliated to a group practice and using a self-contained EHR application were more likely to adopt electronic workflow practices to process examination data. Additionally, GPs were more likely to receive structured examination data than members of other medical specialties when the examination was performed in the practice but were not more likely to receive examination reports from other healthcare professionals in PDF format (Table 4).

\subsection{Administration of referrals and physician's letters}

We assessed the dispatch process and subsequent archiving of referral notes and physician's letters. The vast majority of respondents stated to dispatch referral letters by mail or fax when referring patients to other physicians $(96.3 \%, n=642 / 667)$. Additionally, $46.2 \%(n=308 / 667)$ of the respondents indicated that they occasionally (median $10-20 \%$ of their referrals) also used e-mails and/or online document exchange platforms. Nine respondents $(1.3 \%, n=9 / 667)$ explained to use exclusively emails in this context. Online platforms were solely used in combination with letters and/or e-mails.

After dispatch, $40.2 \%(n=268 / 667)$ of the respondents stated to file their referral notes and physician's letters in a paper-based patient record compared to $37.6 \%(n=251 / 667)$ storing these documents as electronic text files (Table 5). In contrast, 16.0\% ( $n=107 / 667)$ used an electronic storage and a paperbased back-up record. $5.1 \%(n=34 / 667)$ indicated that they have no routine process and archive the documents occasionally in a paper-based record and occasionally as electronic text file. Male, German speaking respondents and those being affiliated to a group practice were most likely to use emails and/or online platforms to dispatch referral notes, whereas the use of a digital document storage was associated with settling in the German language region and EHR adoption Table 4. 
Last Manuscript before press

Djalali S, Ursprung N, Rosemann T, Senn O, Tandjung R: Undirected health IT implementation in ambulatory care favors paper-based workarounds and limits health data exchange. International Journal of Medical Informatics 2015; DOI: 10.1016/j.ijmedinf.2015.08.001. [Epub ahead of print]

\subsection{Intention to expand health IT use}

The majority of respondents $(66.7 \%, n=445 / 667)$ explained that they do not plan to expand their use of health IT within the next 3 years. Among EHR adopters, 43.0\% ( $n=101 / 235)$ were willing to expand health IT use and adopt more electronic workflow processes compared to $28.4 \%$ of the non-EHR adopters. The difference was, however, not significant (Table 4). Respondents from the French and Italian language region as well as those being affiliated to a group practice were most likely to expand their health IT use.

\subsection{Impact of physicians' attitude}

Most respondents (50-63\%) rated the impacts of health IT use on operating costs, expenditures of time, cooperation with other physicians and overview of patients' situation as positive, whereas the impacts on quality of care, workflow processes and physician-patient-relationship were predominantly rated as neutral or negative. In general, EHR adopters rated the impacts of health IT more positive than non-EHR-adopters (Figures 1 and 2).

The individual attitude of the responding physicians towards health IT was determined by a composite score as described in section 2.4. The mean composite score of all respondents was 22.7 (standard deviation (SD) 6.2). Highest scores were observed in physicians aged 30-39 years (mean 26.4, SD 5.9), GPs (mean 23.5, SD 5.6), respondents being affiliated to a group practice (mean 23.7, SD 5.9), with 0-5 years of career in practice (mean 25.9, SD 5.2) and those using a self-contained EHR application (mean 27.3, SD 4.5). The lowest score was observed in respondents without any computer at their disposal (mean 17.9, SD 4.2). Logistic regression showed that physicians' attitude was an independent predictor of EHR adoption, use of electronic billing systems and time schedules, use of electronic laboratory order systems (in-house laboratory services), reception of structured electronic laboratory data, reception of structured examination data (examination performed in the practice) and electronic examination reports (examination performed by external healthcare providers), conversion of paper-based data to an electronic format, and the intention to expand health IT use in the next three years (OR 1.04-1.31 [Table 4]). 


\section{Last Manuscript before press}

Djalali S, Ursprung N, Rosemann T, Senn O, Tandjung R: Undirected health IT implementation in ambulatory care favors paper-based workarounds and limits health data exchange. International Journal of Medical Informatics 2015; DOI: 10.1016/j.ijmedinf.2015.08.001. [Epub ahead of print]

\section{Discussion}

The cross-sectional survey of practice based physicians in Switzerland showed that only a minority of physicians routinely used electronic health data in daily practice. This was the case in particular as regards the documentation of patients' health status over time, the collection of laboratory and examination data and the administration of referral notes and physician's letters. In detail, around $35.5 \%$ of the respondents were considered to use a longitudinal semi-structured electronic text record to document patients' health status including medication, immunization and allergies, whereby only a minority encoded these entries according to a standardized medical classification. Less than $10 \%$ of the physicians who cooperated with an in-house or external laboratory service routinely processed structured electronic laboratory data, i.e. ordered laboratory tests electronically and received the respective results in a structured electronic data format that allows for automatic integration into a preexisting laboratory record. Concerning the results of examination performed in the practice, around $16-26 \%$ of the respondents used such structured electronic data, dependent on the examination type. Concerning examinations performed by external healthcare providers, a minority of $1.3 \%$ of the respondents stated to receive electronic result reports in PDF format. A similar proportion was found concerning the dispatch process of referral notes and physician's letters: only $1.3 \%$ of the respondents constantly relied on e-mail dispatch, the others preferred conventional mail or fax. By contrast, electronic billing systems and time schedules as example of simple electronic features supporting physicians' consultation management were more widespread.

Even though almost every physicians in this study stated to have a computer and access to the internet, it emerged that paper and pen were still physicians' most common instruments of record keeping, and conventional mail and fax messages were their preferred way of exchanging clinical information with other healthcare providers. However, it is to note that physicians could not simply be classified as health IT adopters or deniers. The stepwise assessment of different workflows clearly showed that many physicians cultivated "patchwork" workflows, combining electronic processes and paper-based workarounds.

Depending on the task within a workflow, around $11-46 \%$ of the respondents stated to rely on electronic workflow practices (Table 5). But not a single study respondent stated to always use electronic practices regarding every workflow that was assessed in this study. Thus, none of the respondents could be considered as working in a paperless environment. On the contrary, workflows 


\section{Last Manuscript before press}

Djalali S, Ursprung N, Rosemann T, Senn O, Tandjung R: Undirected health IT implementation in ambulatory care favors paper-based workarounds and limits health data exchange. International Journal of Medical Informatics 2015; DOI: 10.1016/j.ijmedinf.2015.08.001. [Epub ahead of print] in daily practice were apparently inconsistently organized and often characterized by media

disruptions and the simultaneous use of different communication channels within the same practice. For instance, $41.5 \%$ of the respondents stated to dispatch referral letters by e-mail. However, most of them preferred nonetheless the dispatch via letter or fax and used it for $80-90 \%$ of their referral notes. Only $1.3 \%$ of the respondents always relied on e-mail dispatch.

The consistent integration of IT into clinical workflows has already been identified as major challenge for health IT efforts and it has been shown that a lack of integration can cause paper-based workarounds in daily practice $[33,42-45]$. Our study results confirm this hypothesis now and reveal in detail that workarounds do not concern entire workflows. Instead, our stepwise assessment of individual tasks showed that workarounds occur within a workflow whenever data need to be converted and persons involved in the process need to decide whether to take the effort and time to convert data (e.g. by manual data/order entry or scanning) and to maintain an electronic dataflow by all means or not. The laboratory workflow compromising the ordering of tests, the reception and storage of the respective results gives an example: Whereas around $17 \%$ of the respondents stated to use electronic laboratory order systems, only $4-6 \%$ also explained that they would always receive electronic laboratory data that would automatically be integrated into a preexisting electronic laboratory record. Obviously, an electronic order did not necessarily prompt an electronic echo of the connected laboratories. In most cases, the electronic workflow was disrupted.

Another example is the administration of referral notes and physician's letters. It is very likely that these documents are generated with the help of a computer at the time of the year 2013, so it would be natural to dispatch these documents via e-mail and save a copy in a digital storage. However, it is to note that the majority of respondents used conventional mail and fax to dispatch these documents and afterwards $40.2 \%$ stored the documents in a paper-based patient record.

Respondents who documented patients' anamnesis and health status in a longitudinal semi-structured electronic text record were considered to use a self-contained EHR application. Following the approaches of earlier studies in this field [1,29], one could assume, that at least these EHR adopters would always use electronic workflows. However, our approach of a stepwise workflow assessment showed that EHR adoption may be significantly associated with the use of electronic workflow processes but it was not mutually inclusive. The majority of EHR adopters still relied on verbal or written laboratory orders, almost half of them received a relevant proportion of paper-based laboratory 


\section{Last Manuscript before press}

Djalali S, Ursprung N, Rosemann T, Senn O, Tandjung R: Undirected health IT implementation in ambulatory care favors paper-based workarounds and limits health data exchange. International Journal of Medical Informatics 2015; DOI: 10.1016/j.ijmedinf.2015.08.001. [Epub ahead of print] and examination results and the vast majority dispatched referral notes and physician's letters via conventional mail or fax (Table 5).

We explain this finding with the fact that physicians who adopted electronic workflows are still outnumbered by their paper-oriented peers. To be more precise, it must be acknowledged that electronic data exchange needs both, a sender and an addressee. Physicians who decide to exchange data exclusively via e-mail depend on a network of healthcare providers accepting this communication. They take losses as long as only a minority of other healthcare providers has integrated this way of communication into their practice routine. So, it will be more efficient to maintain a conventional letter contact with those healthcare providers who have not yet integrated e-mail and keep all data that are supposed to be exchanged with these addressees in paper format. In conclusion, physicians' adaption to conflicting demands of addressees in their working environment leads to the observed "patchwork" processes. The bottom line is that health IT implementation is synonymous with a disruptive change in the working environment and requires a remodeling of the job design of interconnected health professionals to effectively and efficiently implement technology $[46,47]$. Following the diffusion of innovations theory, the critical mass (late majority) of Swiss physicians implementing a job remodeling is not yet reached [48].

However, several trends can be observed, since the use and exchange of electronic health data varied significantly by language region, medical specialization and practice type of the survey respondents. Obviously, German speaking physicians, those working as a GP and being affiliated to a group practice were more likely to adopt EHR applications and electronic workflow processes (Table 4). We attribute this finding to the fact that members of these subgroups have a stronger demand for health data exchange among each other and will find more peers who already adopted electronic workflows, due to the following circumstances:

a) the German speaking population is larger than the French and Italian population. Consecutively, the commercial offer of health IT applications is larger in the German language region and therefore more likely to attract physicians' interest. Moreover, ambulatory care in the German language region is increasingly characterized by the formation of medical networks that goes along with a higher demand for information exchange among healthcare providers.

b) despite a shortage of young successors, GPs are still the largest group of practice-based physicians in Swiss ambulatory care. They act more than members of other medical 


\section{Last Manuscript before press}

Djalali S, Ursprung N, Rosemann T, Senn O, Tandjung R: Undirected health IT implementation in ambulatory care favors paper-based workarounds and limits health data exchange. International Journal of Medical Informatics 2015; DOI: 10.1016/j.ijmedinf.2015.08.001. [Epub ahead of print] specialties as care coordinators and arrange patients' consultations with specialists. Therefore, they have a greater demand for information exchange with other healthcare providers. By contrast, psychiatrists are the second largest group of physicians but often act in isolation, and are often organized in a single-handed practice without extensive data exchange.

c) the proportion of group practices in Swiss ambulatory care is constantly increasing. Working in a group practice requires more information exchange between physicians and goes along with a reorganization of workflows. Health IT facilitates the team coordination and administration of these practices.

Previous studies in this field suggested that health IT adoption is also associated with age and sex $[5,14,16,29,49-51]$. Our results suggest that young age (30-39 years) and male sex are predictors of EHR adoption but have only limited impact on the adoption of the surveyed electronic workflows supporting health data exchange. We explain this with the fact that physicians' demand for health data exchange depends on the working environment rather than on age and sex.

Another objective of our study was to investigate the effect of physicians' attitude towards health IT on health IT adoption, use of electronic workflow practices and the intention to expand individual health IT use in the future, because a lot of qualitative studies suggested that there exists an association $[5,14,16,29,31-36]$. Indeed, it emerged that physicians' attitude towards health IT was an independent predictor on most outcomes (Table 4). The statistical effect size expressed as odds ratio was, however, limited compared to the effect sizes of the factors language region, medical specialization and practice type. Thus, we conclude that a positive attitude towards health IT promotes the adoption of health IT but does not compensate for a working environment that does not urge physicians to adopt electronic workflow processes.

This finding highlights the value of external incentives. Observations on health IT adoption in the United States and other member states of the Organisation for Economic Co-operation and Development (OECD) suggested that external factors such as financial incentives and legal obligations increase health IT adoption substantially $[1,5,6,20]$. Our results from Switzerland can now be considered as results of a "control group», since the Swiss healthcare system is similarly organized to the healthcare system in the United States or Canada. However, unlike in these countries neither the government nor professional associations have intervened in the Swiss health IT market. Health IT applications do not require accreditation, so the distribution of such applications is 


\section{Last Manuscript before press}

Djalali S, Ursprung N, Rosemann T, Senn O, Tandjung R: Undirected health IT implementation in ambulatory care favors paper-based workarounds and limits health data exchange. International Journal of Medical Informatics 2015; DOI: 10.1016/j.ijmedinf.2015.08.001. [Epub ahead of print] completely subjected to the driving forces of the market economy. Physicians fully take the initial and

ongoing operational costs. The current situation in Switzerland is similar to the situation in the USA prior to the introduction of the HITEC act in 2009, where only few healthcare providers proposed electronic data exchange with other professionals as a requirement for their clinical information systems [9]. Our results show that such situations are not a phenomenon of the 2000s, but remain almost unchanged without interventions at the macro level. One could assume that this could be changed by setting out incentives in the future. In the United States a significant increase of EHR adoption rates was observed following the introduction of incentives based on the HITEC act [52], whereas EHR adoption in Switzerland increases rather slow. Comparing our results to the results of an earlier assessment of EHR diffusion in Switzerland in 2007, an increase of 23.5\% (from $11.7 \%$ to $35.2 \%)$ is stated [29]. Taking into account that the majority of respondents in our study explained that they do not plan to expand their personal health IT use in the next three years, we conclude that it is not likely that the diffusion of EHR or electronic workflow processes will significantly increase in the future without external incentives. Therefore, we recommend the introduction of binding standards of health data exchange between physicians and other healthcare providers that force physicians to adopt electronic workflow processes. Financial rewards for the adoption of these standards and more large-scale clinical trials designed to demonstrate relevant improvements in quality of care gained by health IT implementation could help to convince physicians.

\subsection{Strength and Limitations}

A key strength of this survey study is that we applied a new approach, designed to overcome arbitrary definitions and terminologies in the context of health IT applications. Accordingly, the wording of the questionnaire avoided unstandardized terminologies (e.g. EHR, electronic exchange) in order to prevent misunderstandings of respondents and a consecutive over- or underestimation of the share of EHR adopters with and without multifunctional capacity. Instead, respondents were asked to report separately on their workflows in daily practice that require information exchange between physicians and different healthcare providers. Thus, we enable the international readership to reproduce the workflows task by task and understand where the processes and level of health IT implementation differ from the situation in their own country. This is an advantage over earlier studies comparing the health IT use in different countries $[1,27]$. 


\section{Last Manuscript before press}

Djalali S, Ursprung N, Rosemann T, Senn O, Tandjung R: Undirected health IT implementation in ambulatory care favors paper-based workarounds and limits health data exchange. International Journal of Medical Informatics 2015; DOI: 10.1016/j.ijmedinf.2015.08.001. [Epub ahead of print]

On the other hand, there are also limitations that need to be acknowledged. Our study provides only a

cross-sectional view and its comparability with previous assessments in Switzerland is limited due to the methodological features of the survey instrument. Nevertheless, our study sample can be considered as being representative for the population of physicians in Swiss ambulatory comparing the characteristics of our study respondents to the latest census data of Swiss ambulatory care [53]. Due to this fact and due to the unusually high response rate of $57.1 \%$, the results offer a valuable insight in the current situation.

\subsection{Conclusion}

EHR adoption among physicians in Swiss ambulatory care has slowly increased since 2007. Still, only a few physicians routinely work with electronic health data. Until more of their peers participate in electronic exchange of structured clinical information, most physicians will continue to stay in paperbased systems and workarounds. The survey found that physicians with a positive attitude towards health IT were more likely to adopt electronic workflows, but the impact is minor. It will likely be necessary to introduce financial incentives and develop national standards in order to promote the adoption by a critical mass of practicing clinicians. 
Last Manuscript before press

Djalali S, Ursprung N, Rosemann T, Senn O, Tandjung R: Undirected health IT implementation in ambulatory care favors paper-based workarounds and limits health data exchange. International Journal of Medical Informatics 2015; DOI: 10.1016/j.ijmedinf.2015.08.001. [Epub ahead of print]

Authors contributions

TR, SD and RT developed the study protocol. SD and RT developed the survey instrument. SD and NU collected data. SD and OS performed data analysis. SD drafted the manuscript; all authors read and approved the final manuscript.

\section{Acknowledgements}

This research received funding from the Swiss Institute of Medical Informatics (Institut für Praxisinformatik, IPI). The Swiss Medical Association supported the study by providing the addresses of eligible physicians. The funders and supporters had no role in study design, data collection and analysis, decision to publish, or preparation of the manuscript.

\section{Statements on conflict of interest}

The authors declare no conflict of interests.

\section{Summary table}

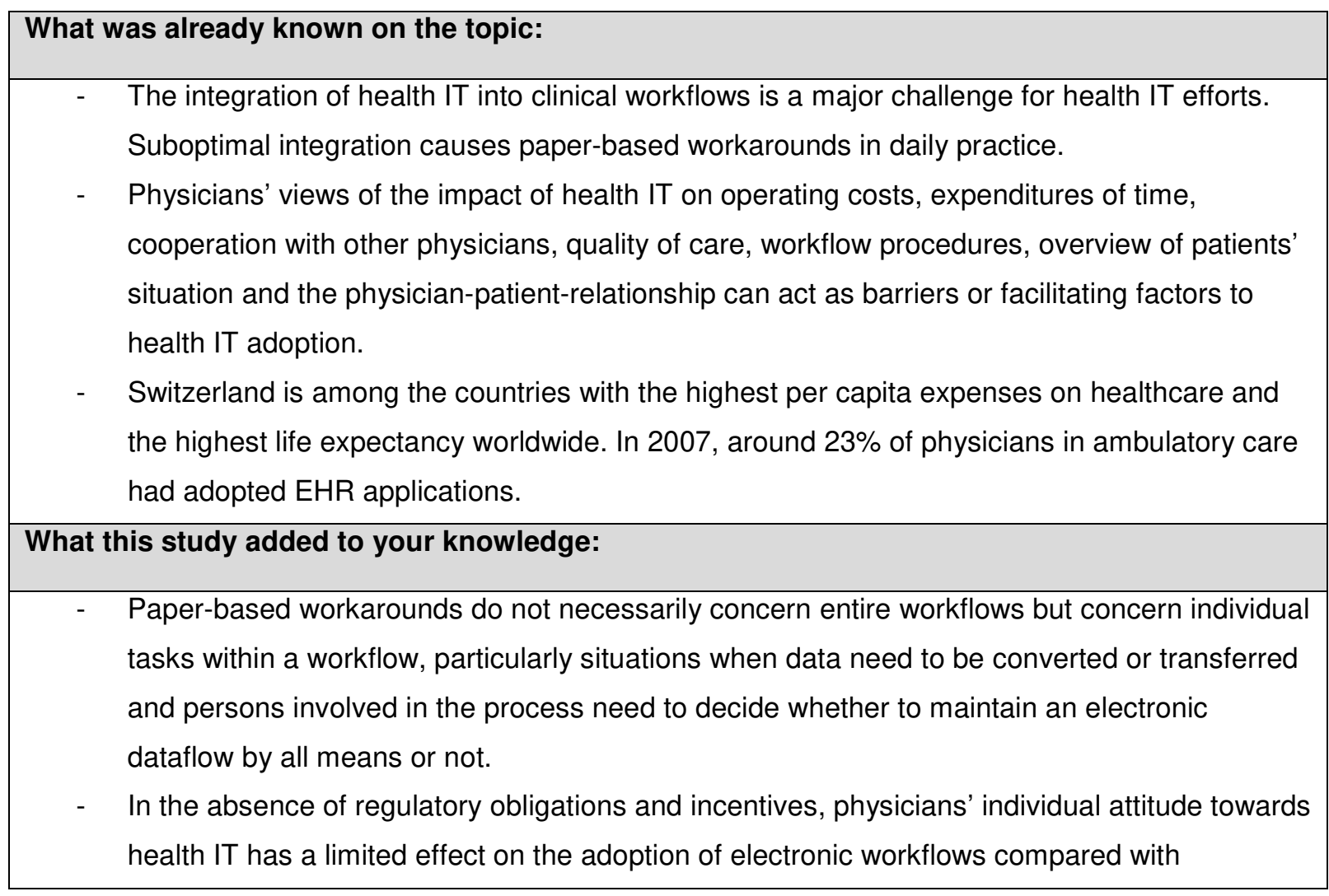




\section{Last Manuscript before press}

Djalali S, Ursprung N, Rosemann T, Senn O, Tandjung R: Undirected health IT implementation in ambulatory care favors paper-based workarounds and limits health data exchange. International Journal of Medical Informatics 2015; DOI: 10.1016/j.ijmedinf.2015.08.001. [Epub ahead of print] contextual factors of the working environment (e.g. regional factors, medical specialty, type of practice)

- In 2013 the estimated rate of EHR adopters among physicians in Swiss ambulatory care was $35.2 \%$. The adoption of electronic workflows was significantly associated with EHR adoption, but taking the EHR adoption rate as surrogate for the uptake of electronic workflows would lead to an overestimation. 


\section{Last Manuscript before press}

Djalali S, Ursprung N, Rosemann T, Senn O, Tandjung R: Undirected health IT implementation in ambulatory care favors paper-based workarounds and limits health data exchange. International Journal of Medical Informatics 2015; DOI: 10.1016/j.jjmedinf.2015.08.001. [Epub ahead of print]

\section{References:}

1. Schoen C, Osborn R, Squires D et al. A Survey of Primary Care Doctors in Ten Countries Shows Progress in Use of Health Information Technology, Less in Other Areas. Health Aff Web First 2012; Nov. 15.

2. Francis J. Global Market for Electronic Health Records (EHR) Expected to Reach \$22.3 Billion by the end of 2015, According to Accenture. Accenture Newsroom 2014;

http://newsroom.accenture.com/news/global-market-for-electronic-health-records-expected-toreach-22-3-billion-by-the-end-of-2015-according-to-accenture.htm ; Accessed 03 October 2014.

3. Adler-Milstein J, Ronchi E, Cohen GR et al. Benchmarking health IT among OECD countries: better data for better policy. Journal of the American Medical Informatics Association : JAMIA 2014; $21: 111-116$.

4. World Health Organisation. Management of patient information: trends and challenges in Member States: based on the findings of the second global survey on eHealth. Global Observatory for eHealth Series, v. 6. 2012; http://apps.who.int/iris/bitstream/10665/76794/1/9789241504645 eng.pdf?ua=1 ; Accessed 06 October 2014.

5. Furukawa MF, King J, Patel V et al. Despite Substantial Progress In EHR Adoption, Health Information Exchange And Patient Engagement Remain Low In Office Settings. Health Aff (Millwood) 2014; 33: 1672-1679.

6. Hsiao CJ, Hing E, Ashman J. Trends in electronic health record system use among officebased Physicians: United States, 2007-2012. National Health Statistics Report 2014; Number 75; May 20, 2014. http://www.cdc.gov/nchs/data/nhsr/nhsr075.pdf ; Accessed 03 October 2014.

7. Li J, Land L, Ray P et al. Health readiness framework from Electronic Health Records perspective. IJIEM 2010; 6: 326.

8. Office of the National Coordinator for Health Information Technology. The ONC-Coordinated Federal Health Information Technology Strategic Plan: 2008-2012. Synopsis. 2008; http://www.healthit.gov/sites/default/files/hit-strategic-plan-summary-508-2.pdf ; Accessed 08 October 2014.

9. Middleton B, Hammond WE, Brennan PF et al. Accelerating U.S. EHR adoption: how to get there from here. recommendations based on the 2004 ACMI retreat. Journal of the American Medical Informatics Association : JAMIA 2005; 12: 13-19.

10. Congress of the United States of America. Health Information technology for Economic and Clinical Health (HITECH) Act. 2009; http://www.healthit.gov/sites/default/files/hitech act excerpt from arra with index.pdf; Accessed 08 October 2014.

11. Stroetmann K, Artmann J, Stroetmann V et al. European Countries on their Journey towards National eHealth Infrastructures. Final European progress report. In: eHealth Strategies; 2011.

12. Boonstra A, Broekhuis M. Barriers to the acceptance of electronic medical records by physicians from systematic review to taxonomy and interventions. BMC Health Serv Res 2010; 10: 231.

13. Vishwanath A, Scamurra SD. Barriers to the adoption of electronic health records: using concept mapping to develop a comprehensive empirical model. Health informatics journal 2007; 13: 119-134. 


\section{Last Manuscript before press}

Djalali S, Ursprung N, Rosemann T, Senn O, Tandjung R: Undirected health IT implementation in ambulatory care favors paper-based workarounds and limits health data exchange. International Journal of Medical Informatics 2015; DOI: 10.1016/j.ijmedinf.2015.08.001. [Epub ahead of print]

14. Jomoom EW, Patel V, Furrukawa MF et al. EHR adopters vs. non-adopters: Impacts of, barries to, and federal initiatives for EHR adoption. Healthcare 2014; 2: 33-39.

15. Linder JA, Schnipper JL, Tsurikova $R$ et al. Barriers to electronic health record use during patient visits. AMIA Annu Symp Proc 2006: 499-503.

16. Li J, Talaei-Khoei A, Seale H et al. Health Care Provider Adoption of eHealth: Systematic Literature Review. Interact J Med Res 2013; 2: e7.

17. Blumenthal D, Tavenner M. The "meaningful use" regulation for electronic health records. N Engl J Med 2010; 363: 501-504.

18. Marcotte L, Seidman J, Trudel $\mathrm{K}$ et al. Achieving meaningful use of health information technology: a guide for physicians to the EHR incentive programs. Archives of internal medicine 2012; 172: 731-736.

19. Jones SS, Rudin RS, Perry T et al. Health information technology: an updated systematic review with a focus on meaningful use. Annals of internal medicine 2014; 160: 48-54.

20. Hsiao CJ, Decker SL, Hing E et al. Most physicians were eligible for federal incentives in 2011, but few had EHR systems that met meaningful-use criteria. Health Aff (Millwood) 2012; 31: 1100-1107.

21. Protti D. Comparison of information technology in general practice in 10 countries. Healthc $Q$ 2007; 10: 107-116.

22. Garett P, Seidman J. EMR vs EHR - What is the Difference? Health IT Buzz Blog, Service of the Office of the National Coordinator for Health Information Technology 2011; http://www.healthit.gov/buzz-blog/electronic-health-and-medical-records/emr-vs-ehrdifference/ ; Accessed 09 October 2014.

23. Markets and Markets. U.S. Electronic Medical Records (EMR - Physician Office \& Hospital) Market - Emerging Trends (Smart Cards, Speech Enabled EMR), Market Share, Winning Strategies, Adoption \& Forecasts till 2015. Report Code: HIT 1618 2011; http://www.marketsandmarkets.com/Market-Reports/us-emr-market-401.html ; Accessed 10 October 2014.

24. Bundesverband Gesungheits-IT (bvitg). Branchenbarometer 2011. 2011; file://fshome/djasi\$/Desktop/bvitg-Branchenbarometer_2011.pdf ; Accessed 10 October 2014.

25. Suisse e. Standards und Architektur - Erste Empfehlungen. 2009; http://www.e-healthsuisse.ch/umsetzung/00146/00148/ ; Accessed 15 October 2014.

26. Chaudhry B, Wang J, Wu S et al. Systematic review: impact of health information technology on quality, efficiency, and costs of medical care. Ann Intern Med 2006; 144: 742-752.

27. Adler-Milstein J, Sarma N, Woskie LR et al. A Comparison Of How Four Countries Use Health IT To Support Care For People With Chronic Conditions. Health Aff (Millwood) 2014; 33: 1559-1566.

28. Kraft E. FMH-Ärztestatistik 2011 - 30849 Ärztinnen und Ärzte für die Schweiz. SÄZ 2012; 93: 309-403.

29. Rosemann $\mathrm{T}$, Marty $\mathrm{F}$, Bhend $\mathrm{H}$ et al. Utilisation of information technologies in ambulatory care in Switzerland. Swiss Medical Weekly 2010; 140: w13088.

30. Guillemin F, Bombardier C, Beaton D. Cross-cultural adaptation of health-related quality of life measures: literature review and proposed guidelines. Journal of clinical epidemiology 1993;

46: 1417-1432. 


\section{Last Manuscript before press}

Djalali S, Ursprung N, Rosemann T, Senn O, Tandjung R: Undirected health IT implementation in ambulatory care favors paper-based workarounds and limits health data exchange. International Journal of Medical Informatics 2015; DOI: 10.1016/j.ijmedinf.2015.08.001. [Epub ahead of print]

31. Dunnebeil S, Sunyaev A, Blohm I et al. Determinants of physicians' technology acceptance for e-health in ambulatory care. Int J Med Inform 2012; 81: 746-760.

32. Ludwick DA, Doucette J. Adopting electronic medical records in primary care: lessons learned from health information systems implementation experience in seven countries. Int $\mathrm{J}$ Med Inform 2009; 78: 22-31.

33. Saleem JJ, Russ AL, Justice CF et al. Exploring the persistence of paper with the electronic health record. Int J Med Inform 2009; 78: 618-628.

34. Venkatesh V, M.G. M, Davies GB et al. User acceptance of Information technology: Toward a Unified View. MIS Quarterly 2003; 27: 425-478.

35. Martin J. Digital doctoring. New York Times 2007; http://www.nytimes.com/2007/04/10/opinion/10iht-edmartin.1.5212649.html; Accessed July 30, 2014.

36. Martins M. New physicians prefer the digital experience. The Health Experience Project 2014; http://thehealthexperienceproject.com/new-physicians-prefer-digital-experience/; Accessed July 30, 2014.

37. Pare G, Raymond L, de Guinea AO et al. Barriers to organizational adoption of EMR systems in family physician practices: a mixed-methods study in Canada. Int J Med Inform 2014; 83: 548-558.

38. Ajami S, Bagheri-Tadi T. Barriers for Adopting Electronic Health Records (EHRs) by Physicians. Acta informatica medica : AIM : journal of the Society for Medical Informatics of Bosnia \& Herzegovina : casopis Drustva za medicinsku informatiku BiH 2013; 21: 129-134.

39. Gagnon MP, Desmartis M, Labrecque M et al. Systematic review of factors influencing the adoption of information and communication technologies by healthcare professionals. Journal of medical systems 2012; 36: 241-277.

40. WONCA. (World Organization of National Colleges, Academies and Academic Associations of General Practitioners/Family Physicians): ICPC-2-R: International Classification of Primary Care. Oxford University Press 2005;

41. Organisation WH. International Classification of Diseases (ICD-10). 2010; http://www.who.int/classifications/icd/en/ ; Accessed 23. October 2014.

42. Saleem JJ, Patterson ES, Militello L et al. Exploring barriers and facilitators to the use of computerized clinical reminders. Journal of the American Medical Informatics Association : JAMIA 2005; 12: 438-447.

43. Kawamoto K, Houlihan CA, Balas EA et al. Improving clinical practice using clinical decision support systems: a systematic review of trials to identify features critical to success. Bmj 2005; 330: 765.

44. Varpio L, Schryer CF, Lehoux P et al. Working off the record: physicians' and nurses' transformations of electronic patient record-based patient information. Acad Med 2006; 81: S35-39.

45. Dykstra RH, Ash JS, Campbell E et al. Persitent Paper: The Myth of "Going Paperless". Unpublished article 2008; .

46. Ford EW, Menachemi N, Phillips MT. Predicting the adoption of electronic health records by physicians: when will health care be paperless? Journal of the American Medical Informatics Association : JAMIA 2006; 13: 106-112. 


\section{Last Manuscript before press}

Djalali S, Ursprung N, Rosemann T, Senn O, Tandjung R: Undirected health IT implementation in ambulatory care favors paper-based workarounds and limits health data exchange. International Journal of Medical Informatics 2015; DOI: 10.1016/j.ijmedinf.2015.08.001. [Epub ahead of print] 47. Ludwick D, Manca D, Doucette J. Primary care physicians' experiences with electronic medical records: implementation experience in community, urban, hospital, and academic family medicine. Canadian family physician Medecin de famille canadien 2010; 56: 40-47.

48. Rogers E. Diffusion of Innovations. 5th edition, Free Press, New York, NY 2003.

49. Pizzi LT, Suh DC, Barone $\mathrm{J}$ et al. Factors related to physicians' adoption of electronic prescribing: results from a national survey. American journal of medical quality : the official journal of the American College of Medical Quality 2005; 20: 22-32.

50. Decker SL, Jamoom EW, Sisk JE. Physicians in nonprimary care and small practices and those age 55 and older lag in adopting electronic health record systems. Health Aff (Millwood) 2012; 31: 1108-1114.

51. Cheung C, Tong E, Cheung NT et al. Factors associated with adoption of the electronic health system among primary care physicians. JMIR Med Inform 2013; 1: e1. doi: 10.2196/medinform.2766.

52. Xierali IM, Hsiao CJ, Puffer JC et al. The rise of electronic health record adoption among family physicians. Ann Fam Med 2013; 11: 14-19.

53. Hostettler S, Kraft E. Neuste Zahlen und Übersicht zur Ärztestatistik 2013. SÄZ 2014; 95: 467473. 
Last Manuscript before press

Djalali S, Ursprung N, Rosemann T, Senn O, Tandjung R: Undirected health IT implementation in ambulatory care favors paper-based workarounds and limits health data exchange. International Journal of Medical Informatics 2015; DOI: 10.1016/j.jmedinf.2015.08.001. [Epub ahead of print]

Tables

Table 1: Criteria for the identification of EHR adopters

\begin{tabular}{|c|c|c|}
\hline andatory criteria & \multirow{4}{*}{ plus } & Minimum one facultative criterion \\
\hline $\begin{array}{l}\text { - The practice's consulting rooms are } \\
\text { equipped with computers }\end{array}$ & & $\begin{array}{ll}\text { - } & \text { Patients drug plan is documented } \\
\text { electronically }\end{array}$ \\
\hline \multirow{2}{*}{$\begin{array}{l}\text { - Patients' anamnesis and current health } \\
\text { status are documented electronically } \\
\text { either during or immediately after the } \\
\text { consultation }\end{array}$} & & $\begin{array}{l}\text { - Patients' immunizations are documented } \\
\text { electronically }\end{array}$ \\
\hline & & 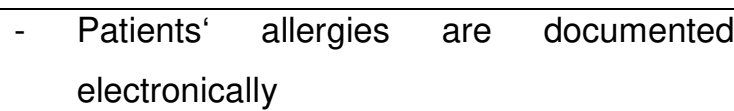 \\
\hline
\end{tabular}

Table 2: Characteristics of included survey respondents*

\begin{tabular}{|c|c|c|}
\hline \multicolumn{3}{|l|}{ Included respondents $n=667$} \\
\hline Age (mean, minimum, maximum) & 54.7 & $(32-79)$ \\
\hline \multicolumn{3}{|l|}{ Sex } \\
\hline - male & $69.1 \%$ & $(n=461)$ \\
\hline - female & $30.4 \%$ & $(n=203)$ \\
\hline \multicolumn{3}{|l|}{ Language region } \\
\hline - German & $71.1 \%$ & $(n=474)$ \\
\hline - French & $26.5 \%$ & $(n=177)$ \\
\hline - Italian & $2.4 \%$ & $(n=16)$ \\
\hline \multicolumn{3}{|l|}{ Medical specialization } \\
\hline - General practitioner (GP) & $41.8 \%$ & $(n=279)$ \\
\hline - Psychiatrist & $17.1 \%$ & $(n=114)$ \\
\hline - Gynaecologist & $7.8 \%$ & $(n=52)$ \\
\hline - Pediatrician & $5.1 \%$ & $(n=34)$ \\
\hline - other specialists & $27.6 \%$ & $(n=184)$ \\
\hline - no clinical activity & $0.1 \%$ & $(n=1)$ \\
\hline \multicolumn{3}{|l|}{ Type of practice } \\
\hline - $\quad$ single-handed practice & $50.7 \%$ & $(\mathrm{n}=338)$ \\
\hline - $\quad$ group practice ( $\geq 2$ physicians) & $48.7 \%$ & $(n=325)$ \\
\hline Duration of practice career (mean, minimum, maximum) & 15.8 & $(0-46)$ \\
\hline
\end{tabular}




\section{Last Manuscript before press}

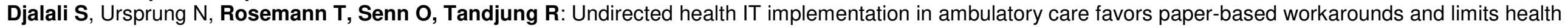
data exchange. International Journal of Medical Informatics 2015; DOI: 10.1016/j.ijmedinf.2015.08.001. [Epub ahead of print]

Table 3: EHR adoption overall and in subgroups of physicians*

\begin{tabular}{|c|c|c|c|}
\hline & EHR adopter & $\begin{array}{l}\text { Non-EHR- } \\
\text { adopter }\end{array}$ & $\begin{array}{c}\text { No } \\
\text { computer }\end{array}$ \\
\hline Overall & $35.2 \%$ & $59.1 \%$ & $4.5 \%$ \\
\hline \multicolumn{4}{|l|}{ Age group (years) } \\
\hline$-\quad 30-39$ & $73.5 \%$ & $26.5 \%$ & $0.0 \%$ \\
\hline$-\quad 40-49$ & $55.4 \%$ & $43.4 \%$ & $0.6 \%$ \\
\hline$-\quad 50-59$ & $31.1 \%$ & $62.3 \%$ & $3.9 \%$ \\
\hline$-\quad 60-69$ & $19.5 \%$ & $73.0 \%$ & $7.5 \%$ \\
\hline$-\quad 70-79$ & $13.3 \%$ & $70.7 \%$ & $16.7 \%$ \\
\hline \multicolumn{4}{|l|}{ Sex } \\
\hline - female & $36.0 \%$ & $53.7 \%$ & $7.4 \%$ \\
\hline - male & $35.1 \%$ & $61.4 \%$ & $3.0 \%$ \\
\hline \multicolumn{4}{|l|}{ Language region } \\
\hline - German & $39.9 \%$ & $55.7 \%$ & $3.6 \%$ \\
\hline - French & $24.3 \%$ & $66.7 \%$ & $6.8 \%$ \\
\hline - Italian & $18.8 \%$ & $75.0 \%$ & $6.3 \%$ \\
\hline \multicolumn{4}{|l|}{ Medical specialization } \\
\hline - $\quad$ General practitioner (GP) & $44.8 \%$ & $54.1 \%$ & $0.7 \%$ \\
\hline - Psychiatrist & $17.5 \%$ & $63.2 \%$ & $18.4 \%$ \\
\hline - Gynaecologist & $26.9 \%$ & $67.3 \%$ & $5.8 \%$ \\
\hline - Pediatrician & $26.5 \%$ & $70.6 \%$ & $0.0 \%$ \\
\hline - $\quad$ other specialists & $36.4 \%$ & $59.2 \%$ & $1.6 \%$ \\
\hline \multicolumn{4}{|l|}{ Type of practice } \\
\hline - $\quad$ single-handed practice & $26.6 \%$ & $66.6 \%$ & $6.2 \%$ \\
\hline - $\quad$ group practice ( $\geq 2$ physicians) & $44.3 \%$ & $51.4 \%$ & $2.5 \%$ \\
\hline \multicolumn{4}{|l|}{ Duration of practice career (years) } \\
\hline$-\quad 0-5$ & $66.7 \%$ & $31.1 \%$ & $0.0 \%$ \\
\hline$-6-10$ & $44.1 \%$ & $54.9 \%$ & $1.0 \%$ \\
\hline$-\quad 11-15$ & $23.7 \%$ & $69.1 \%$ & $5.2 \%$ \\
\hline$-\quad 16-20$ & $24.4 \%$ & $64.2 \%$ & $7.4 \%$ \\
\hline$-\quad>20$ & $20.5 \%$ & $71.9 \%$ & $7.1 \%$ \\
\hline
\end{tabular}

*sums do not necessarily add up to $100 \%$ because of missing data ranging from $0-3.0 \%$ per item. 


\section{Last Manuscript before press}

Djalali S, Ursprung N, Rosemann T, Senn O, Tandjung R: Undirected health IT implementation in ambulatory care favors paper-based workarounds and limits health data exchange. International Journal of Medical Informatics 2015; DOI: 10.1016/j.jimedinf.2015.08.001. [Epub ahead of print] 
Last Manuscript before press

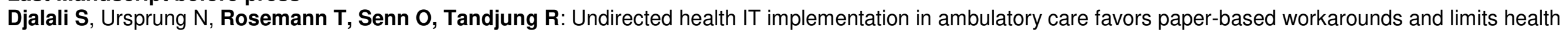
data exchange. International Journal of Medical Informatics 2015; DOI: 10.1016/j.ijmedinf.2015.08.001. [Epub ahead of print]

Table 4: Odds ratio of EHR and electronic workflow adoption in Swiss ambulatory care physicians

\begin{tabular}{|c|c|c|c|c|c|c|c|c|c|c|c|c|c|c|c|c|c|}
\hline \multirow[b]{3}{*}{ Outcome } & \multicolumn{17}{|c|}{ Predictors } \\
\hline & \multicolumn{5}{|c|}{ Age } & \multicolumn{2}{|c|}{ Sex } & \multicolumn{2}{|c|}{ Language region } & \multicolumn{2}{|c|}{$\begin{array}{c}\text { Medical } \\
\text { specialization }\end{array}$} & \multicolumn{2}{|c|}{ Type of practice } & \multicolumn{2}{|c|}{$\begin{array}{l}\text { Composite Score } \\
\text { Attitude }\end{array}$} & \multicolumn{2}{|c|}{ EHR adoption } \\
\hline & $30-39$ & $40-49$ & $50-50$ & $60-69$ & $70-79$ & female & male & German & $\begin{array}{l}\text { French/ } \\
\text { Italian }\end{array}$ & GP & $\begin{array}{c}\text { all other } \\
\text { speciali } \\
\text { sts }\end{array}$ & $\begin{array}{l}\text { practice } \\
(\geq 2 \\
\text { physicia } \\
\text { ns) }\end{array}$ & $\begin{array}{c}\text { single- } \\
\text { handed } \\
\text { practice }\end{array}$ & Score & $\begin{array}{l}\text { median } \\
\text { score } \\
(23 \\
\text { points })\end{array}$ & $\begin{array}{c}\text { EHR } \\
\text { adopter }\end{array}$ & $\begin{array}{l}\text { non- } \\
\text { EHR } \\
\text { adopter }\end{array}$ \\
\hline $\begin{array}{r}\text { EHR adoption } \\
\text { OR } \\
95 \% \mathrm{Cl}\end{array}$ & $\begin{array}{r}3.63 \\
1.22- \\
10.78^{*}\end{array}$ & $\begin{array}{r}1.58 \\
0.93- \\
2.70\end{array}$ & 1.00 & $\begin{array}{r}0.44 \\
0.24- \\
0.80^{\star *}\end{array}$ & $\begin{array}{r}0.55 \\
0.15- \\
1.95\end{array}$ & $\begin{array}{r}0.57 \\
0.34- \\
0.96^{\star}\end{array}$ & 1.00 & $\begin{array}{r}2.25 \\
1.34- \\
3.79^{\star \star}\end{array}$ & 1.00 & $\begin{array}{r}2.21 \\
1.41- \\
3.47^{\star \star \star}\end{array}$ & 1.00 & $\begin{array}{r}1.65 \\
1.05- \\
2.61^{\star}\end{array}$ & 1.00 & $\begin{array}{r}1.31 \\
1.24- \\
1.37^{\star \star \star}\end{array}$ & 1.00 & n.a & n.a \\
\hline $\begin{array}{r}\text { Use of electronic billing systems } \\
\mathrm{OR} \\
95 \% \mathrm{Cl}\end{array}$ & $\begin{array}{r}0.96 \\
0.28- \\
3.17\end{array}$ & $\begin{array}{r}1.00 \\
0.56- \\
1.78\end{array}$ & 1.00 & $\begin{array}{r}0.87 \\
0.53- \\
1.43\end{array}$ & $\begin{array}{r}0.39 \\
0.15- \\
0.95\end{array}$ & $\begin{array}{r}0.67 \\
0.43- \\
1.09\end{array}$ & 1.00 & $\begin{array}{r}0.79 \\
0.50- \\
1.25\end{array}$ & 1.00 & $\begin{array}{r}0.97 \\
0.63- \\
1.50\end{array}$ & 1.00 & $\begin{array}{r}1.24 \\
0.80- \\
1.93\end{array}$ & 1.00 & $\begin{array}{r}1.07 \\
1.02- \\
1.11^{* \star *}\end{array}$ & 1.00 & $\begin{array}{r}5.02 \\
2.54- \\
9.91^{\star \star \star}\end{array}$ & 1.00 \\
\hline $\begin{array}{r}\text { Use of electronic time schedules } \\
\mathrm{OR} \\
95 \% \mathrm{Cl}\end{array}$ & $\begin{array}{r}1.08 \\
0.39- \\
3.01\end{array}$ & $\begin{array}{r}1.99 \\
1.16- \\
3.39^{*}\end{array}$ & 1.00 & $\begin{array}{r}0.77 \\
0.46- \\
1.28\end{array}$ & $\begin{array}{r}0.30 \\
0.09- \\
1.06\end{array}$ & $\begin{array}{r}0.65 \\
0.40- \\
1.06\end{array}$ & 1.00 & $\begin{array}{r}1.42 \\
0.89- \\
2.24\end{array}$ & 1.00 & $\begin{array}{r}0.85 \\
0.55- \\
1.30\end{array}$ & 1.00 & $\begin{array}{r}2.18 \\
1.43- \\
3.34^{\star * *}\end{array}$ & 1.00 & \begin{tabular}{r|}
1.06 \\
$1.01-$ \\
$1.10^{*}$
\end{tabular} & 1.00 & $\begin{array}{r}10.48 \\
6.07- \\
18.12^{\star \star \star}\end{array}$ & 1.00 \\
\hline $\begin{array}{r}\text { Use of electronic laboratory order systems } \\
\text { (in-house lab service) } \\
\text { OR } \\
95 \% \mathrm{Cl}\end{array}$ & $\begin{array}{r}0.29 \\
0.09- \\
0.99\end{array}$ & $\begin{array}{r}0.70 \\
0.33- \\
1.49\end{array}$ & 1.00 & $\begin{array}{r}0.78 \\
0.33- \\
1.82\end{array}$ & $\begin{array}{r}2.86 \\
0.36- \\
23.05\end{array}$ & $\begin{array}{r}0.89 \\
0.43- \\
1.83\end{array}$ & 1.00 & $\begin{array}{c}0.43 \\
0.20- \\
0.91^{*}\end{array}$ & 1.00 & $\begin{array}{r}1.70 \\
0.86- \\
3.32\end{array}$ & 1.00 & $\begin{array}{r}1.33 \\
0.69- \\
2.59\end{array}$ & 1.00 & $\begin{array}{r}1.16 \\
1.08- \\
1.24^{\star \star *}\end{array}$ & 1.00 & $\begin{array}{r}7.02 \\
3.02- \\
16.34^{\star \star *}\end{array}$ & 1.00 \\
\hline $\begin{array}{r}\text { Use of electronic laboratory order systems } \\
\text { (external lab service) } \\
\text { OR } \\
95 \% \mathrm{Cl}\end{array}$ & $\begin{array}{r}1.18 \\
0.43- \\
3.29\end{array}$ & $\begin{array}{r}1.16 \\
0.64- \\
2.12\end{array}$ & 1.00 & $\begin{array}{r}0.96 \\
0.52- \\
1.77\end{array}$ & $\begin{array}{c}1.27 \\
0.30- \\
5.33\end{array}$ & $\begin{array}{r}0.69 \\
0.39- \\
1.21\end{array}$ & 1.00 & $\begin{array}{r}0.17 \\
0.10- \\
0.29^{* \star \star}\end{array}$ & 1.00 & $\begin{array}{r}2.62 \\
1.60- \\
4.27^{* \star *}\end{array}$ & 1.00 & $\begin{array}{r}1.66 \\
1.01- \\
2.73^{\star}\end{array}$ & 1.00 & $\begin{array}{c}1.06 \\
1.00- \\
1.11^{*}\end{array}$ & 1.00 & $\begin{array}{r}1.71 \\
0.93- \\
3.15\end{array}$ & 1.00 \\
\hline $\begin{array}{r}\text { Reception of structured electronic laboratory data } \\
\text { (internal lab service) } \\
\text { OR } \\
95 \% \mathrm{Cl}\end{array}$ & $\begin{array}{r}0.64 \\
0.22- \\
1.92\end{array}$ & $\begin{array}{r}1.30 \\
0.64- \\
2.61\end{array}$ & 1.00 & $\begin{array}{r}0.54 \\
0.23- \\
1.24\end{array}$ & $\begin{array}{r}3.17 \\
0.60- \\
16.85\end{array}$ & $\begin{array}{r}0.79 \\
0.40- \\
1.56\end{array}$ & 1.00 & $\begin{array}{r}8.55 \\
3.54- \\
20.66^{\star \star \star} \\
\end{array}$ & 1.00 & $\begin{array}{r}14.56 \\
7.57 \\
27.99^{\star \star *}\end{array}$ & 1.00 & $\begin{array}{r}3.21 \\
1.7- \\
6.04^{* \star *}\end{array}$ & 1.00 & $\begin{array}{r}1.04 \\
1.04- \\
1.19^{\star \star *}\end{array}$ & 1.00 & $\begin{array}{r}9.61 \\
4.69- \\
19.67^{\star \star \star}\end{array}$ & 1.00 \\
\hline $\begin{array}{r}\text { Reception of structured electronic laboratory data } \\
\text { (external lab service) } \\
\mathrm{OR} \\
95 \% \mathrm{Cl}\end{array}$ & $\begin{array}{r}1.38 \\
0.47- \\
4.06 \\
\end{array}$ & $\begin{array}{l}2.13 \\
1.10- \\
4.14^{*}\end{array}$ & 1.00 & $\begin{array}{r}0.76 \\
0.36- \\
1.60 \\
\end{array}$ & $\begin{array}{r}2.87 \\
0.68- \\
12.06 \\
\end{array}$ & $\begin{array}{r}0.93 \\
0.49- \\
1.76 \\
\end{array}$ & 1.00 & $\begin{array}{r}3.30 \\
1.60- \\
6.80^{* \star *} \\
\end{array}$ & 1.00 & $\begin{array}{r}5.68 \\
3.22- \\
10.00^{\star \star \star} \\
\end{array}$ & 1.00 & \begin{tabular}{r|}
1.98 \\
$1.12-$ \\
$3.48^{\star}$
\end{tabular} & 1.00 & $\begin{array}{r}1.09 \\
1.03- \\
1.15^{\star * \star} \\
\end{array}$ & 1.00 & $\begin{array}{r}9.04 \\
4.89- \\
16.71^{* \star *} \\
\end{array}$ & 1.00 \\
\hline $\begin{array}{l}\text { rt paper-based laboratory reports to an electronic } \\
\text { data format }\end{array}$ & & & & & & & & & & & & & & & & & \\
\hline
\end{tabular}




\section{Last Manuscript before press}

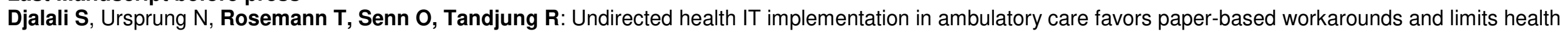
data exchange. International Journal of Medical Informatics 2015; DOI: 10.1016/j.ijmedinf.2015.08.001. [Epub ahead of print]

\begin{tabular}{|c|c|c|c|c|c|c|c|c|c|c|c|c|c|c|c|c|c|}
\hline $\begin{array}{r}\mathrm{OR} \\
95 \% \mathrm{Cl}\end{array}$ & $\begin{array}{r}0.93 \\
0.20- \\
4.40\end{array}$ & $\begin{array}{r}2.44 \\
1.14- \\
5.24^{*}\end{array}$ & 1.00 & $\begin{array}{r}0.48 \\
0.19- \\
1.24\end{array}$ & $\begin{array}{r}0.22 \\
0.52- \\
17.04\end{array}$ & $\begin{array}{r}1.11 \\
0.53- \\
2.34\end{array}$ & 1.00 & $\begin{array}{r}1.14 \\
0.54- \\
2.38\end{array}$ & 1.00 & $\begin{array}{r}1.04 \\
0.54- \\
2.03\end{array}$ & 1.00 & $\begin{array}{r}3.45 \\
1.67- \\
7.11^{* \star \star}\end{array}$ & 1.00 & $\begin{array}{r}1.16 \\
1.08- \\
1.24^{\star \star *}\end{array}$ & 1.00 & $\begin{array}{r}13.40 \\
6.56- \\
27.40^{* * *}\end{array}$ & 1.00 \\
\hline $\begin{array}{r}\text { Reception of structured electronic examination data } \\
\text { (examination performed in the practice) } \\
\text { OR } \\
95 \% \mathrm{Cl}\end{array}$ & $\begin{array}{r}1.66 \\
0.60- \\
4.59\end{array}$ & $\begin{array}{r}1.77 \\
0.95- \\
3.30\end{array}$ & 1.00 & $\begin{array}{r}0.54 \\
0.26- \\
1.11\end{array}$ & $\begin{array}{r}1.39 \\
0.26- \\
7.49\end{array}$ & $\begin{array}{r}0.42 \\
0.22- \\
0.78^{\star \star}\end{array}$ & 1.00 & $\begin{array}{r}3.03 \\
1.58- \\
5.83^{\star \star \star}\end{array}$ & 1.00 & $\begin{array}{r}1.00 \\
0.60- \\
1.69\end{array}$ & 1.00 & $\begin{array}{r}1.04 \\
1.04- \\
3.04^{*}\end{array}$ & 1.00 & $\begin{array}{r}1.09 \\
1.04- \\
1.15^{\star \star *}\end{array}$ & 1.00 & $\begin{array}{r}5.29 \\
2.93- \\
9.53^{* \star *}\end{array}$ & 1.00 \\
\hline $\begin{array}{r}\text { Reception of electronic examination reports from other } \\
\text { physicians } \\
\text { OR } \\
95 \% \mathrm{Cl}\end{array}$ & $\begin{array}{r}1.28 \\
0.50- \\
3.25\end{array}$ & $\begin{array}{r}1.07 \\
0.66- \\
1.74\end{array}$ & 1.00 & $\begin{array}{r}0.82 \\
0.52- \\
1.29\end{array}$ & $\begin{array}{c}0.35 \\
0.13- \\
0.93^{\star}\end{array}$ & $\begin{array}{r}0.75 \\
0.49- \\
1.15\end{array}$ & 1.00 & $\begin{array}{r}3.19 \\
2.13- \\
4.78^{\star * \star}\end{array}$ & 1.00 & $\begin{array}{r}1.44 \\
0.99- \\
2.10\end{array}$ & 1.00 & $\begin{array}{r}1.21 \\
0.83- \\
1.77\end{array}$ & 1.00 & $\begin{array}{r}1.07 \\
1.03- \\
1.11^{* * *}\end{array}$ & 1.00 & $\begin{array}{r}2.03 \\
1.27- \\
3.25^{\star \star *}\end{array}$ & 1.00 \\
\hline $\begin{array}{r}\text { Convert paper-based examniation reports to an } \\
\text { electronic format } \\
\text { OR } \\
95 \% \mathrm{Cl}\end{array}$ & $\begin{array}{r}2.25 \\
0.65- \\
7.84\end{array}$ & $\begin{array}{r}2.45 \\
1.29- \\
4.65^{\star}\end{array}$ & 1.00 & $\begin{array}{c}0.47 \\
0.22- \\
0.97^{\star}\end{array}$ & $\begin{array}{c}0.79 \\
0.17- \\
3.63\end{array}$ & $\begin{array}{r}0.92 \\
0.49- \\
1.71\end{array}$ & 1.00 & $\begin{array}{r}1.68 \\
0.90- \\
3.13\end{array}$ & 1.00 & $\begin{array}{r}1.30 \\
0.76- \\
2.24\end{array}$ & 1.00 & $\begin{array}{r}2.20 \\
1.27- \\
3.80^{\star \star *}\end{array}$ & 1.00 & $\begin{array}{r}1.11 \\
1.06- \\
1.17^{* * *}\end{array}$ & 1.00 & $\begin{array}{r}21.08 \\
11.88- \\
37.39^{* * \star}\end{array}$ & 1.00 \\
\hline $\begin{array}{r}\text { Use of e-mails and/or online platforms when referring } \\
\text { patients to other physicians } \\
\text { OR } \\
95 \% \mathrm{Cl}\end{array}$ & $\begin{array}{r}1.15 \\
0.52- \\
2.56\end{array}$ & $\begin{array}{r}1.18 \\
0.76- \\
1.84\end{array}$ & 1.00 & $\begin{array}{r}0.80 \\
0.52- \\
1.25\end{array}$ & $\begin{array}{r}1.05 \\
0.43- \\
2.54\end{array}$ & $\begin{array}{r}0.60 \\
0.40- \\
0.90^{\star \star}\end{array}$ & 1.00 & $\begin{array}{r}2.25 \\
1.50- \\
3.37^{\star \star *}\end{array}$ & 1.00 & $\begin{array}{r}1.09 \\
0.76- \\
1.55\end{array}$ & 1.00 & $\begin{array}{r}1.47 \\
1.03- \\
2.11^{*}\end{array}$ & 1.00 & $\begin{array}{r}1.04 \\
1.00- \\
1.08^{*}\end{array}$ & 1.00 & $\begin{array}{r}1.23 \\
0.79- \\
1.92\end{array}$ & 1.00 \\
\hline $\begin{array}{r}\text { Use of a digital storage for self-issued referral notes and } \\
\text { physician's letters } \\
\mathrm{OR} \\
95 \% \mathrm{Cl}\end{array}$ & $\begin{array}{c}1.26 \\
0.27- \\
5.79\end{array}$ & $\begin{array}{r}0.98 \\
0.49- \\
1.95\end{array}$ & 1.00 & $\begin{array}{r}0.62 \\
0.35- \\
1.09\end{array}$ & $\begin{array}{c}0.16 \\
0.03- \\
0.72^{\star}\end{array}$ & $\begin{array}{r}0.68 \\
0.39- \\
1.18\end{array}$ & 1.00 & $\begin{array}{r}3.08 \\
1.78- \\
5.35^{\star \star \star}\end{array}$ & 1.00 & $\begin{array}{c}0.69 \\
0.41- \\
1.16\end{array}$ & 1.00 & $\begin{array}{r}1.07 \\
0.64- \\
1.77\end{array}$ & 1.00 & $\begin{array}{r}1.02 \\
0.98- \\
1.07\end{array}$ & 1.00 & $\begin{array}{r}7.13 \\
2.84- \\
17.88^{\star \star \star}\end{array}$ & 1.00 \\
\hline $\begin{array}{r}\text { Intention to expand the use of health IT within the next } 3 \\
\text { years } \\
\mathrm{OR} \\
95 \% \mathrm{Cl}\end{array}$ & $\begin{array}{r}0.75 \\
0.33- \\
1.71\end{array}$ & $\begin{array}{r}0.83 \\
0.53- \\
1.31\end{array}$ & 1.00 & $\begin{array}{r}0.47 \\
0.29- \\
0.77^{\star * *}\end{array}$ & $\begin{array}{r}0.36 \\
0.11- \\
1.15\end{array}$ & $\begin{array}{r}0.69 \\
0.45- \\
1.06\end{array}$ & 1.00 & $\begin{array}{r}0.55 \\
0.37- \\
0.83^{\star \star \star *}\end{array}$ & 1.00 & $\begin{array}{r}1.32 \\
0.91- \\
1.92\end{array}$ & 1.00 & $\begin{array}{r}1.56 \\
1.07- \\
2.29^{\star}\end{array}$ & 1.00 & $\begin{array}{r}1.09 \\
1.05- \\
1.13^{* \star *}\end{array}$ & 1.00 & $\begin{array}{r}1.01 \\
0.64- \\
1.61\end{array}$ & 1.00 \\
\hline
\end{tabular}




\section{Last Manuscript before press}

Djalali S, Ursprung N, Rosemann T, Senn O, Tandjung R: Undirected health IT implementation in ambulatory care favors paper-based workarounds and limits health data exchange. International Journal of Medical Informatics 2015; DOI: 10.1016/j.jimedinf.2015.08.001. [Epub ahead of print]

\section{Table 5: Physicians' adoption of electronic workflow practices when processing laboratory and examination data, referrals and physician's letters}

\begin{tabular}{|c|c|c|c|c|c|c|c|c|c|c|c|c|c|c|}
\hline \multirow[b]{2}{*}{ Process } & \multirow[b]{2}{*}{ Workflow practice } & \multicolumn{13}{|c|}{ Proportion of physicians } \\
\hline & & Overall & $\begin{array}{c}\begin{array}{c}\text { EHR } \\
\text { adopters }\end{array} \\
\end{array}$ & $\begin{array}{l}\text { non-EHR } \\
\text { adopters }\end{array}$ & $\begin{array}{l}\text { German } \\
\text { language } \\
\text { region }\end{array}$ & $\begin{array}{l}\text { French } \\
\text { language } \\
\text { region }\end{array}$ & $\begin{array}{l}\text { Italian } \\
\text { language } \\
\text { region }\end{array}$ & $\begin{array}{c}\text { group } \\
\text { practice } \\
(\geq 2 \\
\text { physician } \\
\text { s) }\end{array}$ & $\begin{array}{l}\text { single- } \\
\text { handed } \\
\text { practice }\end{array}$ & $\begin{array}{l}\text { General } \\
\text { practition } \\
\text { ers (GPs) } \\
\end{array}$ & $\begin{array}{l}\text { Psychiatri } \\
\text { sts }\end{array}$ & $\begin{array}{l}\text { Gynaecol } \\
\text { ogists }\end{array}$ & $\begin{array}{c}\text { Pediatricia } \\
\text { ns }\end{array}$ & $\begin{array}{c}\text { other } \\
\text { specialist } \\
\text { s }\end{array}$ \\
\hline \multicolumn{15}{|l|}{$\begin{array}{l}\text { Processing of laboratory } \\
\text { data }\end{array}$} \\
\hline \multirow{2}{*}{$\begin{array}{l}\text { Ordering laboratory tests } \\
\text { (in-house lab service) }\end{array}$} & Electronic order system & $17.8 \%$ & $37.9 \%$ & $3.6 \%$ & $17.3 \%$ & $18.9 \%$ & $23.1 \%$ & $21.6 \%$ & $13.4 \%$ & $21.3 \%$ & $7.7 \%$ & $4.9 \%$ & $15.6 \%$ & $15.8 \%$ \\
\hline & $\begin{array}{l}\text { Written/verbal instruction to } \\
\text { laboratory staff }\end{array}$ & $82.2 \%$ & $62.1 \%$ & $96.4 \%$ & $82.7 \%$ & $81.1 \%$ & $76.9 \%$ & $78.4 \%$ & $86.6 \%$ & $78.7 \%$ & $92.3 \%$ & $95.1 \%$ & $84.4 \%$ & $84.2 \%$ \\
\hline \multirow{2}{*}{$\begin{array}{l}\text { Ordering laboratory tests } \\
\text { (external lab service) }\end{array}$} & Electronic order system & $16.4 \%$ & $26.7 \%$ & $11.2 \%$ & $12.8 \%$ & $26.7 \%$ & $13.3 \%$ & $20.6 \%$ & $12.2 \%$ & $24.5 \%$ & $0.0 \%$ & $5.9 \%$ & $12.1 \%$ & $13.3 \%$ \\
\hline & $\begin{array}{l}\text { Written/verbal instruction to } \\
\text { laboratory staff }\end{array}$ & $83.6 \%$ & $73.3 \%$ & $88.8 \%$ & $87.2 \%$ & $73.3 \%$ & $86.7 \%$ & $79.4 \%$ & $87.8 \%$ & $75.5 \%$ & $100.0 \%$ & $94.1 \%$ & $87.9 \%$ & $86.7 \%$ \\
\hline \multirow{3}{*}{$\begin{array}{l}\text { Receiving laboratory } \\
\text { results (in-house lab } \\
\text { service) }\end{array}$} & $\begin{array}{l}\text { Always receive structured } \\
\text { electronic laboratory data }\end{array}$ & $14.1 \%$ & $31.4 \%$ & $2.7 \%$ & $16.7 \%$ & $5.3 \%$ & $15.4 \%$ & $17.7 \%$ & $9.8 \%$ & $16.3 \%$ & $7.7 \%$ & $12.2 \%$ & $15.6 \%$ & $7.9 \%$ \\
\hline & $\begin{array}{l}\text { Always receive paper- } \\
\text { based laboratory reports }\end{array}$ & $70.9 \%$ & $37.3 \%$ & $93.0 \%$ & $64.8 \%$ & $89.5 \%$ & $84.6 \%$ & $61.9 \%$ & $81.4 \%$ & $62.4 \%$ & $92.3 \%$ & $85.4 \%$ & $81.3 \%$ & $84.2 \%$ \\
\hline & $\begin{array}{l}\text { Receive a mix of structured } \\
\text { electronic laboratory data } \\
\text { and paper-based } \\
\text { laboratory reports }\end{array}$ & $15.0 \%$ & $31.4 \%$ & $4.3 \%$ & $18.6 \%$ & $5.3 \%$ & $0.0 \%$ & $20.3 \%$ & $8.8 \%$ & $21.3 \%$ & $0.0 \%$ & $2.4 \%$ & $3.1 \%$ & $7.9 \%$ \\
\hline \multirow{3}{*}{$\begin{array}{l}\text { Receiving laboratory } \\
\text { results (external lab } \\
\text { service) }\end{array}$} & $\begin{array}{l}\text { Always receive structured } \\
\text { electronic laboratory data }\end{array}$ & $25.6 \%$ & $57.6 \%$ & $8.1 \%$ & $30.6 \%$ & $12.0 \%$ & $20.0 \%$ & $34.8 \%$ & $16.4 \%$ & $39.9 \%$ & $1.6 \%$ & $23.5 \%$ & $21.2 \%$ & $12.0 \%$ \\
\hline & $\begin{array}{l}\text { Always receive paper- } \\
\text { based laboratory results }\end{array}$ & $50.7 \%$ & $22.4 \%$ & $66.3 \%$ & $50.1 \%$ & $52.0 \%$ & $53.3 \%$ & $40.5 \%$ & $60.6 \%$ & $38.5 \%$ & $87.5 \%$ & $58.8 \%$ & $36.4 \%$ & $57.0 \%$ \\
\hline & $\begin{array}{l}\text { Receive a mix of structured } \\
\text { electronic laboratory data } \\
\text { and paper-based } \\
\text { laboratory reports }\end{array}$ & $23.7 \%$ & $20.0 \%$ & $25.6 \%$ & $19.2 \%$ & $36.0 \%$ & $26.7 \%$ & $24.7 \%$ & $23.0 \%$ & $21.6 \%$ & $10.9 \%$ & $17.6 \%$ & $42.4 \%$ & $31.0 \%$ \\
\hline $\begin{array}{l}\text { Archiving laboratory data } \\
\text { (in-house lab service) }\end{array}$ & $\begin{array}{l}\text { Convert paper-based } \\
\text { laboratory reports to an } \\
\text { electronic data format }\end{array}$ & $19.6 \%$ & $34.7 \%$ & $3.4 \%$ & $17.8 \%$ & $17.3 \%$ & $0.0 \%$ & $19.8 \%$ & $28.1 \%$ & $16.7 \%$ & $17.8 \%$ & $17.3 \%$ & $16.5 \%$ & $19.3 \%$ \\
\hline $\begin{array}{l}\text { Archiving laboratory data } \\
\text { (external lab service) }\end{array}$ & $\begin{array}{l}\text { Convert paper-based } \\
\text { laboratory reports to an } \\
\text { electronic data format }\end{array}$ & $18.4 \%$ & $40.0 \%$ & $6.2 \%$ & $19.0 \%$ & $18.7 \%$ & $0.0 \%$ & $26.0 \%$ & $10.5 \%$ & $18.3 \%$ & $1.6 \%$ & $21.6 \%$ & $12.1 \%$ & $25.3 \%$ \\
\hline
\end{tabular}




\section{Last Manuscript before press}

Djalali S, Ursprung N, Rosemann T, Senn O, Tandjung R: Undirected health IT implementation in ambulatory care favors paper-based workarounds and limits health data exchange. International Journal of Medical Informatics 2015; DOI: 10.1016/j.ijmedinf.2015.08.001. [Epub ahead of print]

\begin{tabular}{|c|c|c|c|c|c|c|c|c|c|c|c|c|c|c|}
\hline \multicolumn{15}{|l|}{$\begin{array}{l}\text { Processing of } \\
\text { examination data }\end{array}$} \\
\hline $\begin{array}{l}\text { Recording } \\
\text { electrocardiogram results } \\
\text { (examination performed in } \\
\text { the practice) }\end{array}$ & $\begin{array}{l}\text { Integration of structured } \\
\text { electronic data into an } \\
\text { electronic examination } \\
\text { record }\end{array}$ & $15.6 \%$ & $32.5 \%$ & $2.0 \%$ & $19.1 \%$ & $6.7 \%$ & $8.3 \%$ & $22.6 \%$ & $7.4 \%$ & $16.7 \%$ & $\begin{array}{c}\text { examination } \\
\text { not } \\
\text { performed }\end{array}$ & $\begin{array}{c}\text { examination } \\
\text { not } \\
\text { performed }\end{array}$ & $15.4 \%$ & $12.1 \%$ \\
\hline $\begin{array}{l}\text { Recording spirometry } \\
\text { results (examination } \\
\text { performed in the practice) }\end{array}$ & $\begin{array}{l}\text { Integration of structured } \\
\text { electronic data into an } \\
\text { electronic examination } \\
\text { record }\end{array}$ & $16.1 \%$ & $31.9 \%$ & $2.5 \%$ & $17.9 \%$ & $9.8 \%$ & $11.1 \%$ & $19.9 \%$ & $10.9 \%$ & $17.9 \%$ & $\begin{array}{l}\text { examination } \\
\text { not } \\
\text { performed }\end{array}$ & $\begin{array}{l}\text { examination } \\
\text { not } \\
\text { performed }\end{array}$ & $8.7 \%$ & $5.9 \%$ \\
\hline $\begin{array}{l}\text { Recording of x-ray results } \\
\text { (examination performed in } \\
\text { the practice) }\end{array}$ & $\begin{array}{l}\text { Digital image integration } \\
\text { into an electronic } \\
\text { examination record }\end{array}$ & $27.6 \%$ & $48.3 \%$ & $9.7 \%$ & $30.8 \%$ & $16.9 \%$ & $20.0 \%$ & $33.5 \%$ & $20.3 \%$ & $26.7 \%$ & $\begin{array}{c}\text { examination } \\
\text { not } \\
\text { performed }\end{array}$ & $\begin{array}{c}\text { examination } \\
\text { not } \\
\text { performed }\end{array}$ & $23.5 \%$ & $30.0 \%$ \\
\hline $\begin{array}{l}\text { Recording of sonography } \\
\text { results (examination } \\
\text { performed in the practice) }\end{array}$ & $\begin{array}{l}\text { Digital image integration } \\
\text { into an electronic } \\
\text { examination record }\end{array}$ & $25.0 \%$ & $44.9 \%$ & $9.8 \%$ & $28.1 \%$ & $14.3 \%$ & $11.1 \%$ & $29.1 \%$ & $19.8 \%$ & $20.1 \%$ & $\begin{array}{c}\text { examination } \\
\text { not } \\
\text { performed }\end{array}$ & $39.1 \%$ & $16.7 \%$ & $28.6 \%$ \\
\hline $\begin{array}{l}\text { Receiving examination } \\
\text { reports from external } \\
\text { healthcare providers }\end{array}$ & $\begin{array}{l}\text { Receive PDF documents } \\
\text { (>50\% of all received } \\
\text { examination reports) }\end{array}$ & $11.4 \%$ & $18.7 \%$ & $4.0 \%$ & $12.3 \%$ & $6.8 \%$ & $16.7 \%$ & $13.6 \%$ & $9.0 \%$ & $12.8 \%$ & $2.3 \%$ & $17.6 \%$ & $13.6 \%$ & $11.5 \%$ \\
\hline $\begin{array}{l}\text { Archiving examination } \\
\text { reports from external } \\
\text { healthcare provider }\end{array}$ & $\begin{array}{l}\text { Convert paper-based } \\
\text { examination reports to an } \\
\text { electronic data format } \\
\text { Digital storage of electronic } \\
\text { examination reports } \\
\text { (PDF documents) }\end{array}$ & $33.2 \%$ & $80.2 \%$ & $7.9 \%$ & $37.6 \%$ & $23.1 \%$ & $12.5 \%$ & $44.3 \%$ & $22.5 \%$ & $41.3 \%$ & $25.0 \%$ & $30.0 \%$ & $27.3 \%$ & $\begin{array}{l}38.2 \% \\
60.6 \%\end{array}$ \\
\hline \multicolumn{15}{|l|}{$\begin{array}{l}\text { Administration of referral } \\
\text { notes and physician's } \\
\text { letters }\end{array}$} \\
\hline \multirow{2}{*}{$\begin{array}{l}\text { Dispatching referral notes } \\
\text { to other physicians }\end{array}$} & $\begin{array}{l}\text { E-Mail and/or online } \\
\text { document exchange } \\
\text { platform }\end{array}$ & $46.2 \%$ & $61.7 \%$ & $39.8 \%$ & $53.0 \%$ & $29.9 \%$ & $25.0 \%$ & $53.5 \%$ & $39.3 \%$ & $51.3 \%$ & $40.4 \%$ & $32.7 \%$ & $64.7 \%$ & $43.5 \%$ \\
\hline & Conventional Mail/Fax & $96.3 \%$ & $95.7 \%$ & $97.0 \%$ & $96.4 \%$ & $95.5 \%$ & $100 \%$ & $95.4 \%$ & $97.6 \%$ & $97.5 \%$ & $95.6 \%$ & $96.2 \%$ & $94.1 \%$ & $96.2 \%$ \\
\hline $\begin{array}{l}\text { Archiving self-issued } \\
\text { referral notes and } \\
\text { physician's letters }\end{array}$ & Digital storage of text files & $37.6 \%$ & $81.7 \%$ & $14.0 \%$ & $43.7 \%$ & $23.2 \%$ & $18.8 \%$ & $48.6 \%$ & $27.2 \%$ & $48.4 \%$ & $14.0 \%$ & $30.8 \%$ & $29.4 \%$ & $39.7 \%$ \\
\hline
\end{tabular}




\section{Last Manuscript before press}

Djalali S, Ursprung N, Rosemann T, Senn O, Tandjung R: Undirected health IT implementation in ambulatory care favors paper-based workarounds and limits health data exchange. International Journal of Medical Informatics 2015; DOI: 10.1016/j.ijmedinf.2015.08.001. [Epub ahead of print]

\section{Figures}

Figure 1: Respondents' rating of the impact of health IT on operating costs, time savings, cooperation with other physicians, quality of care, workflow management, and physicians' ability to get an overview of patients' situation

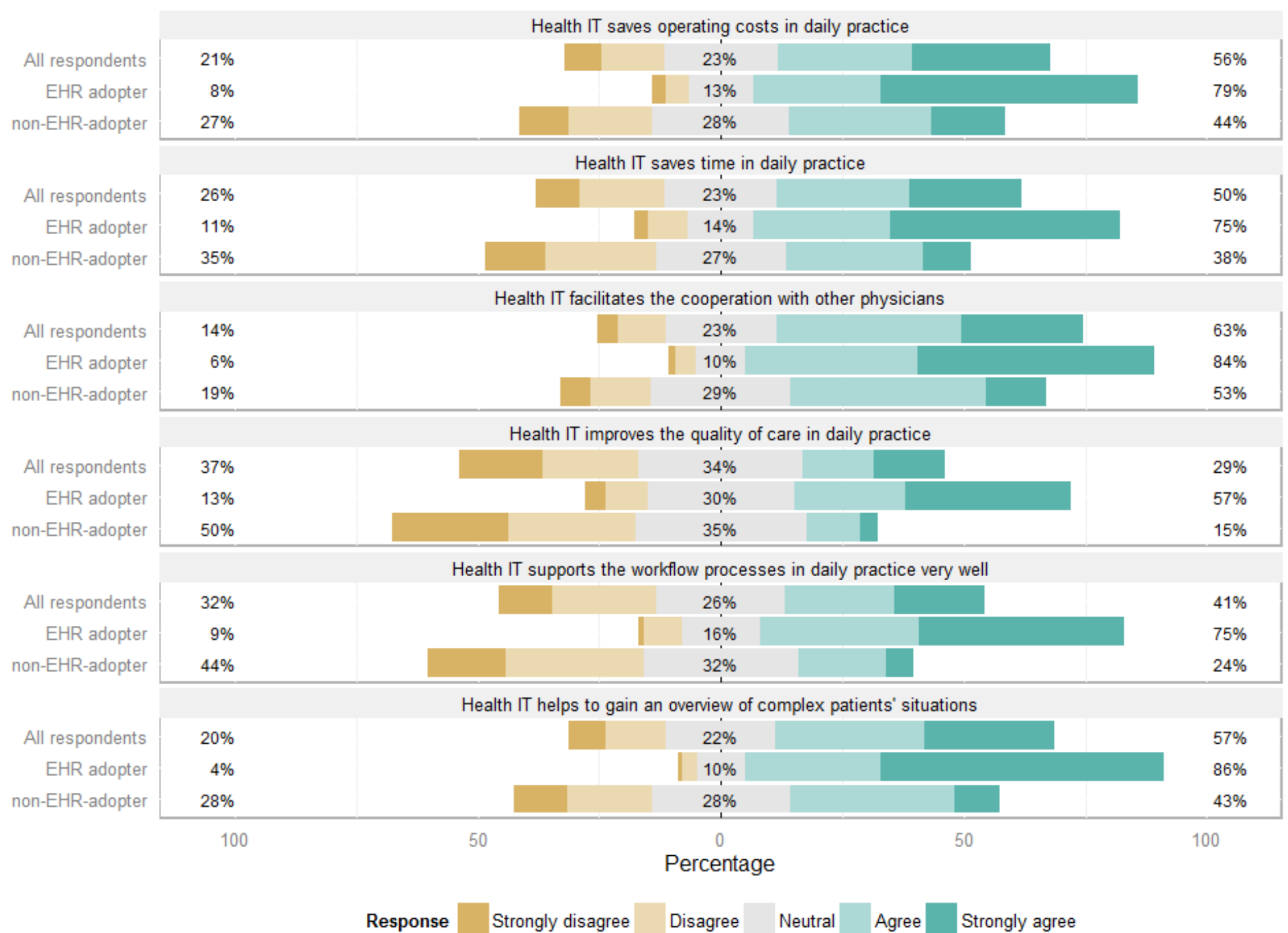




\section{Last Manuscript before press}

Djalali S, Ursprung N, Rosemann T, Senn O, Tandjung R: Undirected health IT implementation in ambulatory care favors paper-based workarounds and limits health data exchange. International Journal of Medical Informatics 2015; DOI: 10.1016/j.ijmedinf.2015.08.001. [Epub ahead of print]

Figure 2: Respondents's rating of the impact of health IT on physician-patient-relationship

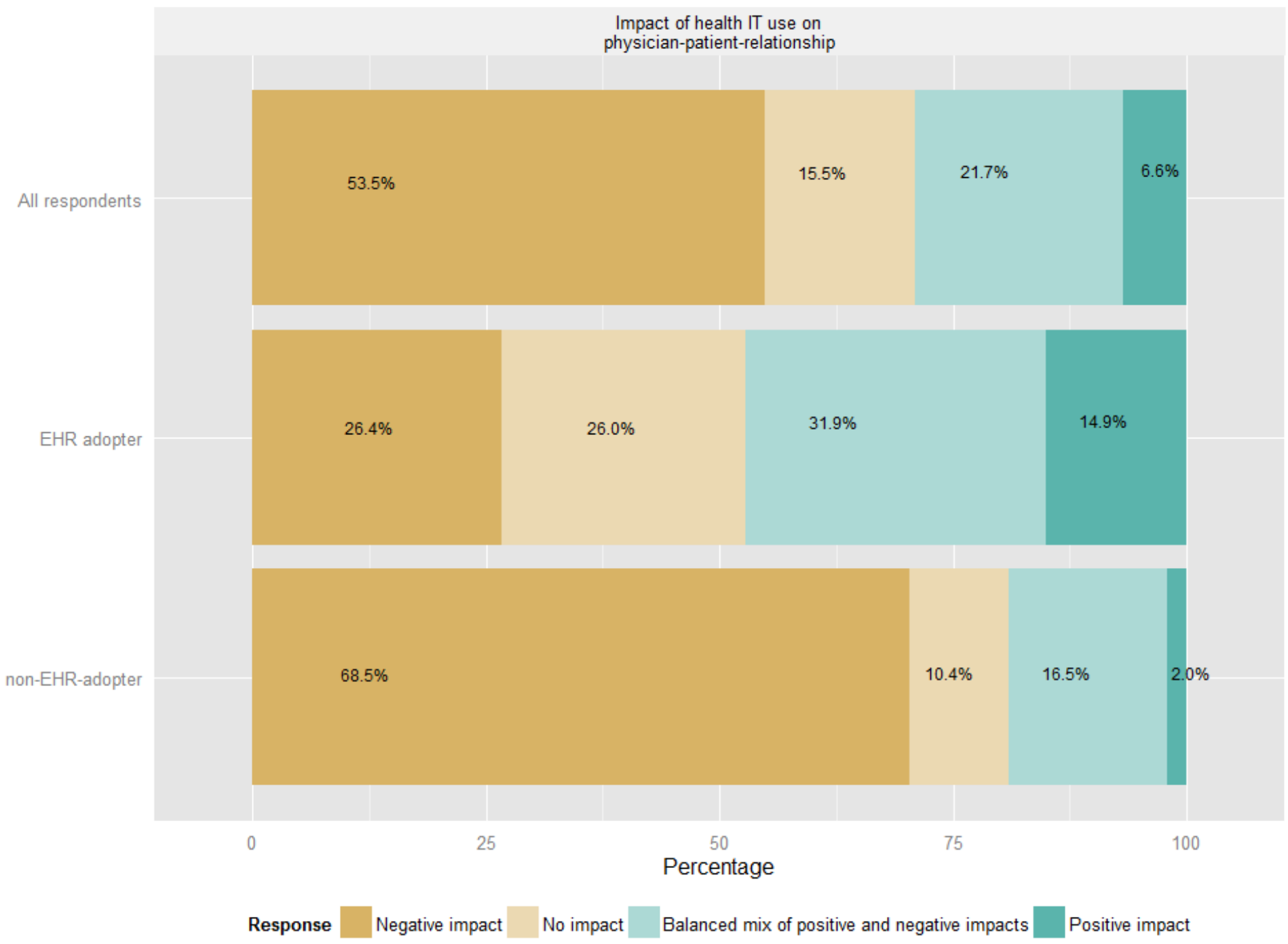

